\title{
Article \\ Green Synthesis of Iron-Doped Cobalt Oxide Nanoparticles from Palm Kernel Oil via Co-Precipitation and Structural Characterization
}

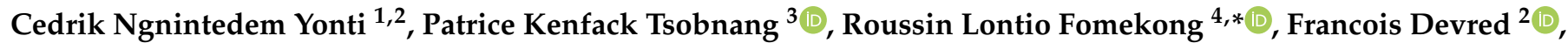 \\ Eric Mignolet ${ }^{5}$, Yvan Larondelle ${ }^{5}$, Sophie Hermans ${ }^{2}{ }^{\mathbb{D}}$, Arnaud Delcorte ${ }^{2}{ }^{\mathbb{D}}$ and John Lambi Ngolui ${ }^{4}$ \\ 1 Inorganic Chemistry Department, University of Yaoundé I, Yaoundé 812, Cameroon; \\ cedrik.ngnintedem@uclouvain.be \\ 2 Institute of Condensed Matter and Nanosciences, Catholic University of Louvain, Croix du Sud, \\ B-1348 Louvain-la-Neuve, Belgium; francois.devred@uclouvain.be (F.D.); \\ sophie.hermans@uclouvain.be (S.H.); arnaud.delcorte@uclouvain.be (A.D.) \\ 3 Chemistry Department, Faculty of Science, University of Dschang, Dschang 67, Cameroon; \\ pakenfack@gmail.com \\ 4 Chemistry Department, Higher Teacher Training College, University of Yaoundé I, Yaoundé 47, Cameroon; \\ jngolui@gmail.com \\ 5 Louvain Institute of Biomolecular Science and Technology, Catholic University of Louvain, Croix du Sud, \\ B-1348 Louvain-la-Neuve, Belgium; eric.mignolet@uclouvain.be (E.M.); yvan.larondelle@uclouvain.be (Y.L.) \\ check for \\ updates \\ * Correspondence: lonforou@yahoo.fr
}

Citation: Ngnintedem Yonti, C.; Kenfack Tsobnang, P.; Lontio

Fomekong, R.; Devred, F.; Mignolet, E.; Larondelle, Y.; Hermans, S.; Delcorte, A.; Lambi Ngolui, J. Green Synthesis of Iron-Doped Cobalt Oxide Nanoparticles from Palm Kernel Oil via Co-Precipitation and Structural Characterization. Nanomaterials 2021, 11, 2833. https://doi.org/10.3390/ nano11112833

Academic Editor: José Luis Barriada Pereira

Received: 19 September 2021

Accepted: 18 October 2021

Published: 25 October 2021

Publisher's Note: MDPI stays neutral with regard to jurisdictional claims in published maps and institutional affiliations.

\section{Copyright: (c) 2021 by the authors.} Licensee MDPI, Basel, Switzerland. This article is an open access article distributed under the terms and conditions of the Creative Commons Attribution (CC BY) license (https:// creativecommons.org/licenses/by/ $4.0 /)$.

\begin{abstract}
In this study, a bio-derived precipitating agent/ligand, palm kernel oil, has been used as an alternative route for the green synthesis of nanoparticles of $\mathrm{Fe}$-doped $\mathrm{Co}_{3} \mathrm{O}_{4}$ via the co-precipitation reaction. The palm oil was extracted from dried palm kernel seeds by crushing, squeezing and filtration. The reaction of the palm kernel oil with potassium hydroxide, under reflux, yielded a solution containing a mixture of potassium carboxylate and excess hydroxide ions, irrespective of the length of saponification. The as-obtained solution reacts with an aqueous solution containing iron and cobalt ions to yield the desired metallo-organic precursor, iron cobalt carboxylate. Characterization of the precursors by IR and gas chromatography (GC) attests to the presence of carboxylate fatty acids in good agreement with the proportion contained in the oil, and ICP confirms that the metallic ratios are in the proportion used during the synthesis. Analysis of the products thermally decomposed between $400{ }^{\circ} \mathrm{C}$ and $600^{\circ} \mathrm{C}$ by XRD, EDX, TEM and ToF-SIMS, established that cobalt iron oxide nanoparticles $\left(\mathrm{Co}_{(1-\mathrm{x})} \mathrm{Fe}_{\mathrm{x}}\right)_{3} \mathrm{O}_{4}$ were obtained for $\mathrm{x} \leq 0.2$ and a nanocomposite material $\left(\mathrm{Co}_{(1-\mathrm{x})} \mathrm{Fe}_{\mathrm{x}}\right)_{3} \mathrm{O}_{4} / \mathrm{Fe}_{3} \mathrm{O}_{4}$ for $x \geq 0.2$, with sizes between 22 and $9 \mathrm{~nm}$. ToF-SIMS and XRD provided direct evidence of the progressive substitution of cobalt by iron in the $\mathrm{Co}_{3} \mathrm{O}_{4}$ crystal structure for $\mathrm{x} \leq 0.2$.
\end{abstract}

Keywords: green synthesis; palm kernel oil; carboxylate fatty acids; co-precipitation method; Fe-doped $\mathrm{Co}_{3} \mathrm{O}_{4}$

\section{Introduction}

In the last three decades, much research has been devoted to the synthesis and characterization of materials at the nano scale. Nanomaterials exhibit unique properties with respect to their bulk counterparts mainly because of size-dependent effects [1]. As the size of a system decreases, the surface area increases, changing mechanical, thermal, optical and catalytic properties significantly [2]. Transition metal oxide nanoparticles have attracted considerable attention and cobalt oxide, in particular, exhibits specific chemical and thermal stability [3]. It is well known as a photocatalyst [4], a catalyst in $\mathrm{N}_{2} \mathrm{O}$ decomposition [5], a highly selective CO sensor [6], a high temperature solar selective absorber [7], an electrode material for thin film supercapacitor [8], a magnetic material [9] and it is used in electrochromic devices [10], because its optical properties changes under an external electrical stimulus. 
$\mathrm{Co}_{3} \mathrm{O}_{4}$ is a black antiferromagnetic p-type semiconductor material, which crystallizes in a normal spinel structure with the chemical formula $\mathrm{AB}_{2} \mathrm{O}_{4}$, based on a cubic closepacking structure of oxide ions, with $\mathrm{Co}^{2+}$ ions occupying eight tetrahedral A-sites and $\mathrm{Co}^{3+}$ ions occupying 16 octahedral B-sites. $\mathrm{Co}_{3} \mathrm{O}_{4}$ nanoparticles have been extensively studied [11-14]. In particular, the modification of their properties by progressively substituting the Co metal ions in their structure with other metal ions (Mg and $\mathrm{Ni}[14], \mathrm{Fe}[5,15,16]$, $\mathrm{Mn}$ [17,18], Cd [19], $\mathrm{Cu}$ [20], Pd [21], Mo [22]), thus, forming a mixed cobalt oxide, is rather well established. Thus, the synthesis of cobalt oxide and mixed cobalt oxides using various routes has been reported, including the facile solvothermal route [23], chemical spray pyrolysis [7], chemical vapor deposition [10], sol-gel [24], hydrothermal [25], simple combustion [26] and co-precipitation methods [5]. Co-precipitation, in particular, is a simple, low-cost method that is used for the preparation of simple metal oxides and hetero-atom metal oxides. The main advantages of this synthesis method are that it allows the control of the stoichiometry of the final product and that it does not require a sophisticated high vacuum or high temperature system. For example, using this method, mixed cobalt iron oxide nanoparticles could be obtained by thermally decomposing a precursor pre-synthesized via the reaction between a cobalt iron salt solution and an O-donor ligand.

Many O-donor ligands (carboxylates) have been used for the synthesis of simple and mixed metal oxides in the last few decades like oxalates [15,17], malonates [27,28], succinates [28,29], acetylacetonates [30,31] and octanoates [32]. Most of the carboxylate ligands used for that purpose are generally synthetic whereas some are readily available in our environment (mostly in plants [33]). They can be used as a green and renewable source of ligand for the synthesis of the precursor. These green sources include, amongst others, citric acid, tartaric acid, oxalic acid and the linear long-carbon chain fatty acids. The linear long-carbon chain fatty acids are the major component of every vegetal oil, especially palm kernel oil. They are present in vegetable oils in the mono-, di- or tri-ester form from which the corresponding acid can be easily released by a simple saponification reaction. Therefore, the possibility of using this natural, readily available, renewable and sustainable source of carboxylate ligands for the synthesis of simple and hetero-metal oxide nanoparticles of cobalt and iron is explored in this study. It could also open up the possibility of high exploitation of non-edible oil. Many of such green syntheses have been reported recently for the synthesis of cobalt oxide nanoparticles [34-42], even though palm kernel oil was not used as in the present study.

Palm kernel oil is extracted from the palm kernel/nuts of the palm oil tree, Alaeis guinensis, and contains about $82 \%$ saturated fatty acid. In Cameroon, it is mostly used for the fabrication of soap and in the skin protection while in the USA, Europe and Malaysia, hydrogenation and fractionation products of palm kernel oil are used for chocolate-type couvertures, biscuit cream fillings, sugar confectionery, coffee creamers, imitation creams, to replace butterfat in filled milk [43-45].

In this paper, we report, for the first time and to the best of our knowledge, the use of a carboxylate ligand extracted from palm kernel oil, a Cameroonian local oil product, as the precipitating agent for synthesis of mixed cobalt-iron oxide, $\left(\mathrm{Co}_{(1-\mathrm{x})} \mathrm{Fe}_{\mathrm{x}}\right)_{3} \mathrm{O}_{4}(\mathrm{x} \leq 20)$ and nanocomposite materials, $\left(\mathrm{Co}_{(1-\mathrm{x})} \mathrm{Fe}_{\mathrm{x}}\right)_{3} \mathrm{O}_{4} / \mathrm{Fe}_{3} \mathrm{O}_{4}(\mathrm{x}>20)$ by thermally decomposing the precursor (hetero-metal carboxylate) pre-synthesized via a simple co-precipitation reaction The nature of the precursor was partially elucidated using Fourier transform infrared (FTIR) spectroscopy, thermogravimetric analysis (TGA), gas chromatography (GC) and inductively coupled plasma-atomic emission spectroscopy (ICP-AES). The structure and stoichiometry of the hetero-atom metal oxide nanoparticles obtained were determined by XRD, FTIR, EDX-SEM, ToF-SIMS, XPS and TEM.

\section{Materials and Methods}

\subsection{Materials}

Palm kernel seeds were purchased in the local market. Cobalt(II) chloride hexahydrate $\left(\mathrm{CoCl}_{2} \cdot 6 \mathrm{H}_{2} \mathrm{O}, 98 \%\right.$, Sigma Aldrich, St. Louis, MO, USA), Cobalt(II) nitrate hexahydrate 
$\left(\mathrm{Co}\left(\mathrm{NO}_{3}\right)_{2} \cdot 6 \mathrm{H}_{2} \mathrm{O}, \geq 99.0 \%\right.$, Sigma Aldrich, Darmstadt, Germany), Iron(III) nitrate nonahydrate $\left(\mathrm{Fe}\left(\mathrm{NO}_{3}\right)_{3} \cdot 9 \mathrm{H}_{2} \mathrm{O}\right.$, Sigma Aldrich, St. Louis, $\left.\mathrm{MO}, \mathrm{USA}\right)$ potassium hydroxide $(\mathrm{KOH}$, $\geq 85 \%$ Carl Roth, Karlsruhe, Germany), sulfuric acid (95\%, VWR, Fontenay sous bois, France), nitric acid (65\%, VWR, Darnstadt, Germany) and hexane (97\%, VWR, Gliwice, Poland) were used as received, without further purification.

\subsection{Methods}

$\left(\mathrm{Co}_{(1-\mathrm{x})} \mathrm{Fe}_{\mathrm{x}}\right)_{3} \mathrm{O}_{4}$ and $\left(\mathrm{Co}_{(1-\mathrm{x})} \mathrm{Fe}_{\mathrm{x}}\right)_{3} \mathrm{O}_{4} / \mathrm{Fe}_{3} \mathrm{O}_{4}$ nanoparticles were obtained via five experimental steps: 1 . Extraction of palm kernel oil from palm kernel seeds; 2 . Synthesis of the carboxylate (using the saponification reaction); 3. Titration of the carboxylate; 4. Synthesis of cobalt iron carboxylate precursors and finally 5 . Thermal decomposition of the precursors.

\subsubsection{Extraction of Palm Kernel Oil}

The extraction of the palm kernel oil from palm kernel seeds was carried out using classical traditional methods in the western region of Cameroon. The palm kernel seeds were spread out on a metal plate with small holes connected to a terracotta oven. After drying, the palm kernel seeds were then poured into an electric grinder which separates the hot black palm kernel oil from the pulp of the palm kernel shells. Filtration then yields the pure yellow palm kernel oil.

\subsubsection{Carboxylate Synthesis}

The carboxylate ligands were generated via a saponification reaction between the palm kernel oil (9.98 g) and $30 \mathrm{~mL}$ of aqueous $\mathrm{KOH}(1.375 \mathrm{~mol} / \mathrm{L})$, at $96^{\circ} \mathrm{C}$, under reflux, varying the time of the saponification reaction $(2 \mathrm{~h}, 3 \mathrm{~h}, 6 \mathrm{~h}, 7 \mathrm{~h}, 8 \mathrm{~h})$. The same reaction was carried out by doubling the oil mass for $2 \mathrm{~h}$ of reaction time. Each obtained solution was transferred to a decanted funnel containing $10 \mathrm{~mL}$ of hexane. The mixture was homogenized and left to stand for $24 \mathrm{~h}$. It forms two phases, an aqueous phase containing carboxylates, and a non-aqueous phase.

\subsubsection{Titration of Carboxylate Solution}

The amount of carboxylate in the aqueous phase is determined by $\mathrm{pH}$-metric titration. The $\mathrm{pH}$-meter was calibrated by two buffer solution ( $\mathrm{pH}=7$ and 10$) .5 \mathrm{~mL}$ of the aqueous phase are homogenized in $15 \mathrm{~mL}$ of distilled water and titrated with sulfuric acid $(0.25 \mathrm{M})$. From the titration curves, we determined the concentration of the obtained carboxylates, the remaining hydroxide ions, and deduced the amount of metal ions likely to react.

\subsubsection{Synthesis of the Cobalt Iron Carboxylate Precursors}

The titration curves allowed us to adopt two synthesis routes: first synthesis route and second synthesis route, both depending on the nature of the carboxylate solution obtained in Section 2.2.2 above. The same amount of the carboxylate solution; for each synthesis route, was used to synthesize cobalt iron carboxylate precursors The first synthesis route used the carboxylate solution as obtained, resulting from the saponification reaction between $9.98 \mathrm{~g}$ of palm kernel oil and $30 \mathrm{~mL}$ of $\mathrm{KOH}$ solution $(1.375 \mathrm{~mol} / \mathrm{L})$ during $2 \mathrm{~h}$. For example, in order to obtain a precursor containing $90 \%$ of cobalt and $10 \%$ of iron (mole/mole), an aqueous solution of $0.516 \mathrm{~g}$ of $\mathrm{CoCl}_{2} \cdot 6 \mathrm{H}_{2} \mathrm{O}$ and $0.097 \mathrm{~g}$ of $\mathrm{Fe}$ $\left(\mathrm{NO}_{3}\right)_{3} \cdot 9 \mathrm{H}_{2} \mathrm{O}$ was added dropwise in a beaker containing $5 \mathrm{~mL}$ of potassium carboxylate solution. The precipitate formed was rinsed with distilled water and dried. The second synthesis route used the carboxylate solution resulting from the saponification reaction between the double mass of oil $(19.8 \mathrm{~g})$ and $30 \mathrm{~mL}$ of $\mathrm{KOH}$ solution $(1.375 \mathrm{~mol} / \mathrm{L})$. All the excess hydroxide ions were neutralized by nitric acid prior to the addition of the metallic solution. For example, for the synthesis of the precursor containing the same proportion of cobalt and iron as above, $2.5 \mathrm{~mL}$ of nitric acid $(0.25 \mathrm{M})$ were added dropwise using a burette to $3.8 \mathrm{~mL}$ solution of potassium carboxylate. To this solution, an aqueous solution 
of $0.218 \mathrm{~g}$ of $\mathrm{Co}\left(\mathrm{NO}_{3}\right)_{2} \cdot 6 \mathrm{H}_{2} \mathrm{O}$ and $0.0337 \mathrm{~g}$ of $\mathrm{Fe}\left(\mathrm{NO}_{3}\right)_{3} \cdot 9 \mathrm{H}_{2} \mathrm{O}$ was added dropwise. The precipitate thus obtained was then rinsed with distilled water and dried.

Samples are designated by the letter $S$ (first synthesis route), $S^{\prime}$ (second synthesis route) and a number which represents the expected percentage of iron in the compound. For example, sample S10/S'10 is the one that contains $10 \%$ of iron and $90 \%$ of cobalt. The carboxylate ligand is represented by RCOO. The amounts of metallic reagents used during the synthesis are presented in Table 1.

Table 1. Amounts of the metallic reagents used during the synthesis.

\begin{tabular}{ccccccccc}
\hline Reagents (g) & S0 & S1 & S2 & S3 & S4 & S10 & S20 & S30 \\
\hline $\mathrm{CoCl}_{2} \cdot 6 \mathrm{H}_{2} \mathrm{O}$ & 0.602 & 0.593 & 0.584 & 0.576 & 0.567 & 0.516 & 0.438 & 0.367 \\
$\mathrm{Fe}\left(\mathrm{NO}_{3}\right)_{3} \cdot 9 \mathrm{H}_{2} \mathrm{O}$ & 0 & 0.010 & 0.020 & 0.030 & 0.040 & 0.097 & 0.186 & 0.267 \\
\hline & $\mathrm{S}^{\prime} 0$ & $\mathrm{~S}^{\prime} 1$ & $\mathrm{~S}^{\prime} 2$ & $\mathrm{~S}^{\prime} 3$ & $\mathrm{~S}^{\prime} 4$ & $\mathrm{~S}^{\prime} 10$ & $\mathrm{~S}^{\prime} 20$ & $\mathrm{~S}^{\prime} 30$ \\
\hline $\mathrm{Co}\left(\mathrm{NO}_{3}\right)_{2} \cdot 6 \mathrm{H}_{2} \mathrm{O}$ & 0.243 & 0.241 & 0.238 & 0.236 & 0.233 & 0.219 & 0.194 & 0.170 \\
$\mathrm{Fe}\left(\mathrm{NO}_{3}\right)_{3} \cdot 9 \mathrm{H}_{2} \mathrm{O}$ & 0.000 & 0.003 & 0.007 & 0.010 & 0.013 & 0.034 & 0.067 & 0.101 \\
\hline
\end{tabular}

\subsubsection{Thermal Decomposition of the Precursors}

The cobalt iron carboxylates obtained were thermally decomposed in a ceramic combustion boat holder between $400{ }^{\circ} \mathrm{C}$ and $600{ }^{\circ} \mathrm{C}$ in a thermal oven for one hour at a heating rate of $10^{\circ} \mathrm{C} / \mathrm{min}$ under air atmosphere. The thermal decomposition process/temperature was followed/determined by thermogravimetry.

\subsubsection{Characterization of the Precursors and Final Products}

Metallic elemental analyses of the precursors were performed via inductively coupled plasma-atomic emission spectroscopy (ICP-AES) using the Thermo scientific ICAP 6500 Duo (Watham, MA, USA). $\sim 40 \mathrm{mg}$ of sample were digested in $4 \mathrm{~mL}$ of mixed acid ( $3 \mathrm{~mL}$ of concentrated nitric acid and $1 \mathrm{~mL}$ of concentrated hydrochloric acid) and the mixture diluted with $500 \mathrm{~mL}$ distilled water. Measurements were carried out on this final solution.

The functional groups in the precursors and the calcined products were determined using the Nicolet Nexus 870 Fourier transform infrared (FTIR) spectrometer (Madison, WI, USA) and the Thermo Scientific Nicolet iN10 infrared microscope (Waltham, MA, USA) in transmission mode. All samples were prepared by the method of $\mathrm{KBr}$ pellets except precursors obtained by the second synthesis route which were simply squeezed onto a transparent KRS-5 crystal. The spectra were recorded with 64 scans at $4 \mathrm{~cm}^{-1}$ resolution for the Nicolet Nexus 870 spectrometer and with 64 scans at $16 \mathrm{~cm}^{-1}$ for the Scientific Nicolet iN10 infrared microscope, all in the $4000-500 \mathrm{~cm}^{-1}$ range, in transmission mode.

The content of the carboxylates present in the precursors was determined by gas chromatography and then compared with those present in the oil. Carboxylates were slowly released from the metallo-organic precursors by their reaction with $50 \mathrm{~mL}$ of sulfuric acid $0.25 \mathrm{M}$ at about $70{ }^{\circ} \mathrm{C}$ under magnetic stirring. This formed an oily layer of carboxylic fatty acid, which coagulated after cooling. It was washed, filtered and, as for palm kernel oil, esterified by the method described by Folch et al. [46]. This method involves a saponification with $0.1 \mathrm{M} \mathrm{KOH} / \mathrm{MeOH}$ at $70^{\circ} \mathrm{C}$ for $1 \mathrm{~h}$, followed by esterification using a $1.2 \mathrm{M} \mathrm{HCl} / \mathrm{MeOH}$ solution at $70{ }^{\circ} \mathrm{C}$ for $20 \mathrm{~min}$. An HPLC grade hexane-water solvent (95:5) was used to extract the methylated fatty acids. They were finally analyzed by GC trace gas chromatography (Thermoquest; Milan, Italy) equipped with a flame ionisation detector. For the chromatographic separation, a restek RT2560 capillary column (0.25 $\mathrm{mm}$ in diameter, $100 \mathrm{~m}$ in length) coated with a polar stationary phase of $0.2 \mu \mathrm{m}$ thickness (Bellefonte, PA, USA) was used. The carrier gas, hydrogen, was maintained at a constant pressure of $200 \mathrm{KPa}$. The column of temperature was programmed as follows: $80{ }^{\circ} \mathrm{C}$ for $0 \mathrm{~min}$; $80-175^{\circ} \mathrm{C}$ for $3.8 \mathrm{~min}\left(25^{\circ} \mathrm{C} / \mathrm{min}\right) ; 175^{\circ} \mathrm{C}$ for $30 \mathrm{~min}$; $175-205^{\circ} \mathrm{C}$ for $3 \mathrm{~min}\left(10{ }^{\circ} \mathrm{C} / \mathrm{min}\right) ; 205^{\circ} \mathrm{C}$ for $4 \mathrm{~min} ; 205-225^{\circ} \mathrm{C}$ for $2 \mathrm{~min}\left(10^{\circ} \mathrm{C} / \mathrm{min}\right) ; 225^{\circ} \mathrm{C}$ for $20 \mathrm{~min}$. and $225-80{ }^{\circ} \mathrm{C}$ for $7.25 \mathrm{~min}\left(20^{\circ} \mathrm{C} / \mathrm{min}\right)$. The detector temperature was set at $280{ }^{\circ} \mathrm{C}$. 
Hydrogen and air flow rates for the detector were maintained throughout all runs at 35 and $350 \mathrm{~mL} / \mathrm{min}$, respectively. A calibration mixture of fatty acids standards was processed in parallel. The data were analyzed by a chromquest 3.0 software (Thermo Fisher, Waltham, MA, USA).

Thermal behavior of the precursor was studied by thermogravimetric analysis (TGA) on a METTLER TOLEDO Thermal Analyzer (Columbus, $\mathrm{OH}$, USA) in air at a flow rate of $100 \mathrm{~mL} . \mathrm{min}^{-1}$, a heating rate of $10^{\circ} \mathrm{C} \mathrm{min}{ }^{-1}$ and a temperature range of $25-600{ }^{\circ} \mathrm{C} / 900{ }^{\circ} \mathrm{C}$.

XRD measurements of the calcined precursors were performed using a Bruker D8 advanced diffractometer (Bruker, karlshube, Germany) equipped with a linkeye XE-T detector and $\mathrm{Cu}$ source. The two-theta range from 5 to $80^{\circ}$ was scanned with an increment of $0.015^{\circ}$ and an integration time of $0.15 \mathrm{~s}$ using a Bragg Brentano geometry. For the experiment, the decomposition product was spread out on the silicon plate in such a manner as to avoid preferred orientations. The Bruker software DIFFRAC.EVA (version V4.2, Karlsruhe, Germany) was used for data processing using either the COD or PDF 2 database for phase identification.

Raman spectroscopy was carried out using a confocal Microscope DXR Raman ThermoScientifc inc. model (Madison, WI, USA) equipped with a diode light (785 nm). The resolution was set to $4 \mathrm{~cm}^{-1}$. The number of scans was 10 and the time of accumulation was $10 \mathrm{~s}$ per scan. The laser power was set to $10 \mathrm{~mW}$ and the $50 \times$ objective was used.

The surface chemical composition of the decomposition product was determined by $X$ ray photoelectron spectroscopy (XPS) using a SSX 100/206 photoelectron spectrometer from Surface Science Instruments (Mountain view, CA, USA) equipped with a monochromatized micro focused Al X-ray source (powered at $20 \mathrm{~mA}$ and $10 \mathrm{kV}$ ).

The morphologies of the sample were investigated by transmission electron microscopy using the TEM Leo922 (Zeiss, Germany) with an accelerating voltage of $120 \mathrm{kV}$. TEM samples were prepared by dropping a sonicated water dispersion suspension of the powder samples on a carbon-coated copper grid.

Chemical characterisations of the samples were carried out using a TOF.SIMS 5 instrument (IONTOF GmbH, Münster, Germany). A pulsed $\mathrm{Bi}_{5}{ }^{+}$metal ion source was used to produce a primary beam with an acceleration voltage of $30 \mathrm{kV}$ to bombard powder samples pressed onto the adhesive part of Post-it ${ }^{\circledR}$ papers. An AC target current of $0.08 \mathrm{pA}$ with a bunched pulse width lower than 1 ns was used. Both positive and negative secondary ion species were analysed. For spectra acquisition, a raster of $128 \times 128$ data points over an area of $250 \times 250 \mu \mathrm{m}^{2}$ was used. The total primary ion beam dose for each analysed area was always kept below $5 \times 10^{10}$ ions. $\mathrm{cm}^{-2}$, ensuring static conditions. Lateral resolution of $\sim 3 \mu \mathrm{m}$ and mass resolution $\mathrm{m} / \Delta \mathrm{m}>5000$ at $29 \mathrm{~m} / z$ were maintained for positive and negative spectra acquisition. Charge compensation was achieved by interlaced electron flood gun $\left(E_{k}=20 \mathrm{eV}\right)$. All data analyses were carried out using the software supplied by the instrument manufacturer, SurfaceLab (version 6.8; Münster, Germany).

\section{Results and Discussion}

\subsection{Titration Curves of the Carboxylates Solutions}

Figure 1 presents the titration curves of the carboxylate solutions obtained.

The average concentration of all the carboxylate solutions is $1.01 \mathrm{~mol} / \mathrm{L}$. All curves look like a titration of a strong acid with a solution containing both strong and weak base. This means that, in addition of the carboxylate formed, hydroxide ions (strong base) remain in the solutions obtained. The quantity of remaining hydroxide ions decreases with the time of the saponification reaction from $2 \mathrm{~h}$ until $6 \mathrm{~h}$ and then, remains constant. However, the same quantity of hydroxide ions is obtained for only $2 \mathrm{~h}$ when the initial quantity of oil is doubled. Thus, two different synthesis routes have been adopted: Using the carboxylate solution as obtained for $2 \mathrm{~h} / 9.98 \mathrm{~g}$ of oil of the precursor (first synthesis route), and using the carboxylate obtained for $2 \mathrm{~h} / 19.8 \mathrm{~g}$ of oil prior to the neutralization of all the excess hydroxide ion (second synthesis route). 


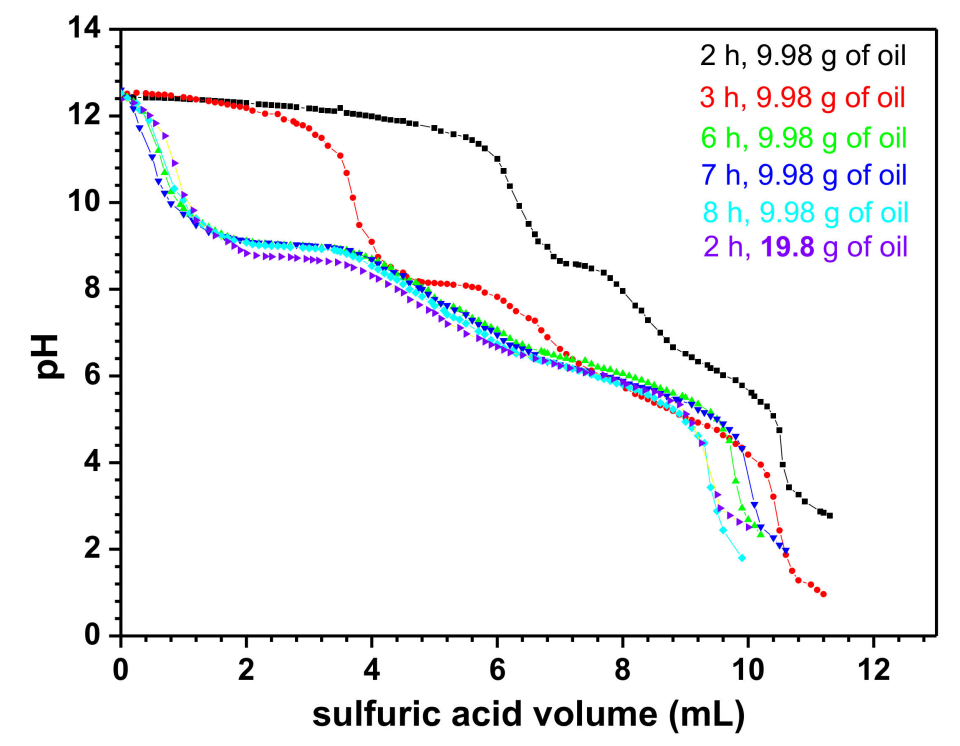

Figure 1. The pH-metric titration curve between obtained carboxylate solution and sulfuric acid solution.

\subsection{ICP-AES Analysis of the Precursors}

The ratios between metals contained in the precursors were determined using ICPAES. The results are presented in the Table 2 and are compared with those calculated from the concentrations of reagents.

Table 2. Comparison between expected and obtained mole ratio of metal in the precursors.

\begin{tabular}{|c|c|c|c|c|c|c|c|c|c|c|}
\hline & & Elements & S0/S'0 & $\mathrm{S} 1 / \mathrm{S}^{\prime} 1$ & $\mathrm{~S} 2 / \mathrm{S}^{\prime} 2$ & S3/S'3 & $S 4 / S^{\prime} 4$ & $\mathrm{~S} 10 / \mathrm{S}^{\prime} 10$ & S20/S'20 & $\mathrm{S} 30 / \mathrm{S}^{\prime} 30$ \\
\hline \multirow{2}{*}{$\begin{array}{l}\text { Found } \\
\text { experi- } \\
\text { mentally }\end{array}$} & $\begin{array}{c}\text { First syn- } \\
\text { thesis } \\
\text { route }\end{array}$ & $\mathrm{Fe} / \mathrm{Co}$ & 0.000 & 0.0103 & 0.0210 & 0.0319 & 0.0428 & 0.113 & 0.247 & 0.414 \\
\hline & $\begin{array}{l}\text { Second } \\
\text { synthe- } \\
\text { sis } \\
\text { route }\end{array}$ & $\mathrm{Fe} / \mathrm{Co}$ & 0.000 & 0.0116 & 0.0200 & 0.0315 & 0.0396 & 0.0974 & 0.219 & 0.440 \\
\hline \multicolumn{2}{|c|}{ calculated } & $\mathrm{Fe} / \mathrm{Co}$ & 0.000 & 0.0101 & 0.0204 & 0.0309 & 0.0417 & 0.111 & 0.250 & 0.429 \\
\hline
\end{tabular}

The results reveal that the ratios of metallic ions present in the precursor correspond to the expected value which confirms that the synthetic method adopted was good.

\subsection{Fourier Transform Infrared (FTIR) Spectral Characterization of the Precursor}

Figure 2 shows IR spectra of the obtained precursors. To this effect, samples S0, S10, S20 and S30 were selected as being more representative of the eight samples for the first synthesis route while samples $S^{\prime} 0, S^{\prime} 10, S^{\prime} 20, S^{\prime} 30$ were chosen for the second synthesis method. 


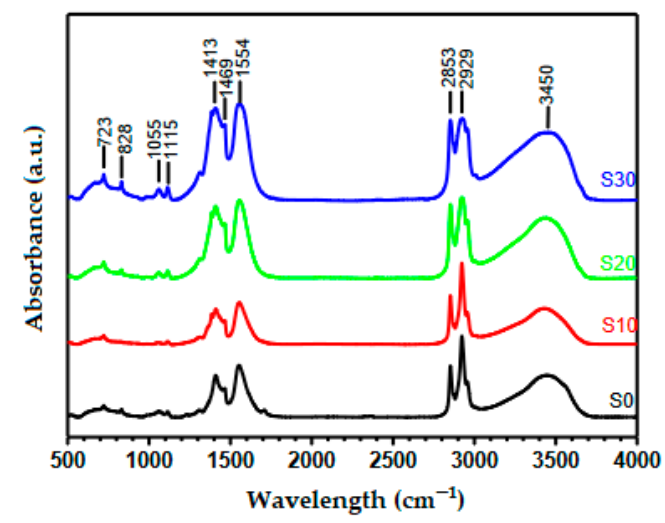

(a)

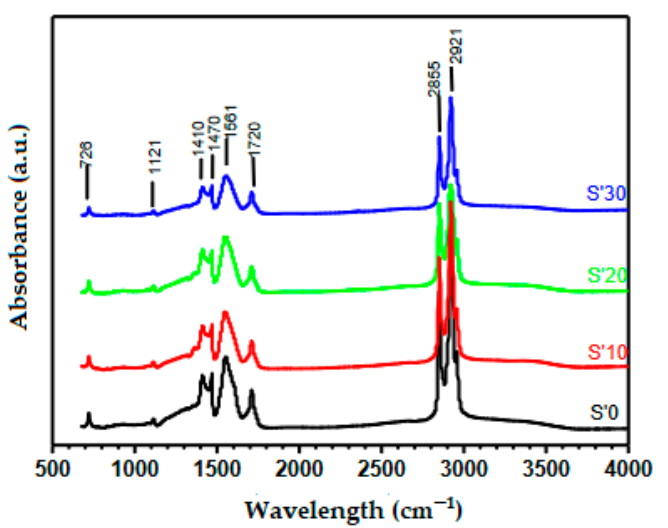

(b)

Figure 2. Fourier transform infrared (FTIR) spectra of samples (a) S0, S10, S20, S30 and (b) S’0, S'10, $S^{\prime} 20, S^{\prime} 30$.

Figure 2 shows that in all the samples, the peaks characteristic of the symmetric and asymmetric stretching vibrations of carboxylic group OCO are observed, respectively, at $1410-1413 \mathrm{~cm}^{-1}$ and $1554-1561 \mathrm{~cm}^{-1}$. This attests the presence of carboxylate groups in the samples. The peaks at 1297 and $1469 \mathrm{~cm}^{-1}$ are being assigned to the bending vibrations of the $\mathrm{C}-\mathrm{H}$ while that at $1115-1120 \mathrm{~cm}^{-1}$ is being attributed to $\mathrm{C}-\mathrm{O}$ stretching and that at $723-726 \mathrm{~cm}^{-1}$ to the bending deformation of OCO. The intense peaks at $2853 \mathrm{~cm}^{-1}$ and $2929 \mathrm{~cm}^{-1}$ are typical of the aliphatic symmetric and asymmetric stretches, respectively, of the $-\mathrm{CH}$ group. It should be noted that the peak at $1720 \mathrm{~cm}^{-1}$ characteristic of the $\mathrm{C}=\mathrm{O}$ double bond of the carboxylate group present in the $\mathrm{S}^{\prime}$ samples, is practically absent in the $S$ samples. Since for all the $S$ samples obtained by the 1st synthesis route there is no residual carboxylate acid present, it implies that the entire carboxylate group is engaged in the formation of the coordination compound. Kamta et al., working with the octanoate ligand (a C-8 straight-chain carboxylate) and employing the same synthesis method, obtained similar results [32]. The prominent $-\mathrm{OH}$ peak observed at $3450 \mathrm{~cm}^{-1}$ for $\mathrm{S}$ samples (Figure 2a) are absent in the $\mathrm{S}^{\prime}$ samples (Figure $2 \mathrm{~b}$ ). This is ample proof that all the excess $\mathrm{OH}^{-}$ions were completely neutralized in the $\mathrm{S}^{\prime}$ samples prior to the reaction with the metal salt solutions.

\subsection{Gas Chromatography (GC) Analysis}

Table 3 compares the carboxylate contents (\%) in the precursors and in the palm kernel oil.

These results in Table 2 show that the palm kernel oil used in this work is saturated at $86.25 \%$ with $47.16 \%$ of lauric acid. This is in agreement with the literature which estimates the average percentage of saturated fatty acid at about $82 \%$ with $48 \%$ of lauric acid $[45,47]$. The high proportion of saturated fatty acid found in the precursors $(88.33 \%$ of saturated acid with $52.75 \%$ of lauric acid) indicates that the carboxylates present in the oil are almost completely released in solution irrespective of their molar masses. From Table 3, it is evident that the relative proportions of the carboxylates present in the palm kernel oil and in the metallo-organic precursors are comparable. The table also shows that the principal fatty acids in the palm kernel oil and the precursors are, respectively lauric acid, myristic acid, oleic acid and palmitic acid, caprilic, capric, linoleic and stearic. 
Table 3. Carboxylate contents in the metallo-organic precursors and the palm kernel oil.

\begin{tabular}{ccc}
\hline Acids & Palm Kernel Oil (\%) & Metallo-Organic Precursors (\%) \\
\hline Lauric acid, C12:0 & 47.16 & 52.75 \\
Myristic acid, C14:0 & 16.89 & 18.60 \\
Oleic acid, C18:1; cis9 & 13.90 & 11.05 \\
Palmitic acid, C16:0 & 8.48 & 9.35 \\
Caprilic acid, C8:0 & 4.11 & 1.34 \\
Capric acid, C10:0 & 3.59 & 2.85 \\
Linoleic acid, C18:2; C9C12 & 2.29 & 0.22 \\
Stearic acid, C18:0 & 2.79 & 2.91 \\
Caproic acid, C6:0 & 0.36 & 0.26 \\
Arachidic acid, C20:0 & 0.12 & 0.12 \\
Oleic acid C18:1; cis11 & 0.11 & 0.09 \\
Tridecylic acid C13:0 & 0.10 & 0.12 \\
Arachidic acid C20:1; C11 & 0.08 & 0.05 \\
Pentadecylic acid C15:0 & 0.02 & 0.03 \\
Oleic acid C18:1; trans9 & 0.00 & 0.10 \\
Arachidic acid C20:2; C11, C14 & 0.00 & 0.10 \\
\hline
\end{tabular}

\subsection{Thermogravimetry Analysis of the Precursors}

Figure $3 \mathrm{a}, \mathrm{b}$ give the comparative thermogravimetric and differential thermal analysis (DTA) curves of S samples (S0, S10, S20, S30) and $S^{\prime}$ samples (S'0, S'10, S'20, S'30), respectively. The weight loss peaks have been determined by a graph of the weight difference for consecutive rows against the temperature (called DTA curves). The thermogravimetric (thermograms) and DTA curves, of all the samples synthesized with the same synthesis route have similar thermal behavior. However, it should be noted that for samples obtained by the first synthesis method, those in which cobalt is substituted by iron (S10, S20, S30) decompose at a lower temperature.

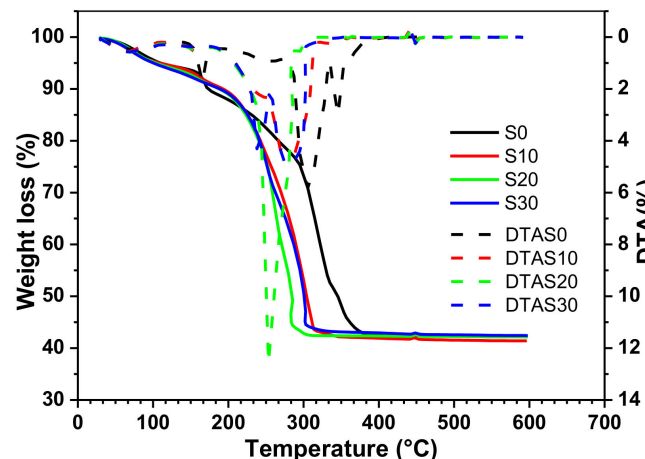

(a)

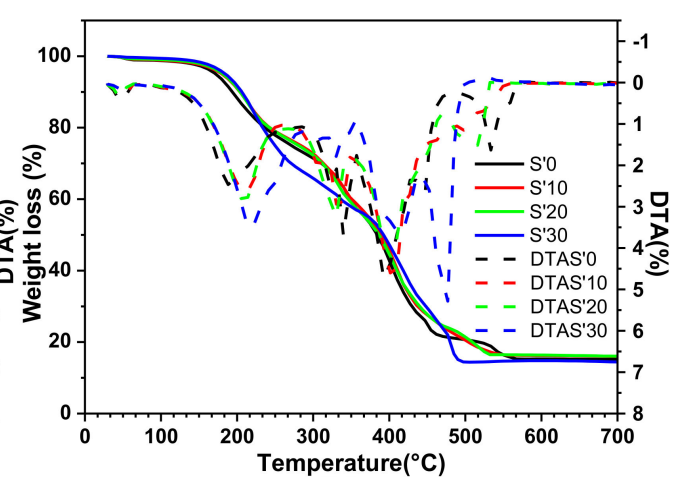

(b)

Figure 3. Thermogravimetric analysis (TGA) and differential thermal analysis (DTA) curves for samples (a) S0, S10, S20, S30; (b) S'0, S'10, S'20, S’30.

DTA curves of S samples S0, S10, S20, S30 show that their decompositions follow three main steps. Taking the DTA curve for the $\mathrm{S} 0$ as an illustration, the maximum weight losses occurs around 165,305 and $345{ }^{\circ} \mathrm{C}$. The weak weight loss $(\sim 5.9 \%)$ observed between $70{ }^{\circ} \mathrm{C}$ and $170{ }^{\circ} \mathrm{C}$ is attributed to 0.75 molecules of water of crystallization. A major peak $(48.18 \%)$ occurring between $170{ }^{\circ} \mathrm{C}$ and $370{ }^{\circ} \mathrm{C}$ is being attributed to the loss of the organic part of the precursor. All the decomposition product residues correspond to a total weight loss of $\sim 61 \%$ and no further weight loss is observed beyond $370{ }^{\circ} \mathrm{C}$. Therefore, this explains why $400{ }^{\circ} \mathrm{C}$ was adopted as the thermal decomposition temperature for all the $\mathrm{S}$ samples. On the other hand, DTA curves for the $S^{\prime}$ samples ( $\left.S^{\prime} 0, S^{\prime} 10, S^{\prime} 20, S^{\prime} 30\right)$ show five main steps, generally with some overlapping. For example, for the $S^{\prime} 0$ sample, the weight loss peaks occur around $190,340,400,450$ and $553^{\circ} \mathrm{C}$. They all completely decompose around $570{ }^{\circ} \mathrm{C}$ 
with a total weight loss of $85.3 \%$, the reason why $600{ }^{\circ} \mathrm{C}$ was chosen as the decomposition temperature for all the $S^{\prime}$ samples. Comparing the total weight loss of $\sim 61 \%$ for the $S$ samples (those with $\mathrm{OH}^{-}$ions present) to that of $85.3 \%$ for the $\mathrm{S}^{\prime}$ samples (those with the carboxylate group linked directly to the metal), it is evident that the $S^{\prime}$ samples yield the desired results given that their theoretical total weight loss is $84 \%$. This assertion is confirmed by the absence of an $-\mathrm{OH}$ peak at $3450 \mathrm{~cm}^{-1}$ in the IR spectra for the $\mathrm{S}^{\prime}$ samples (see the $-\mathrm{OH}$ peak observed for the $\mathrm{S}$ samples). According to previous results published by Kamta et al. [29], the formula proposed for the compounds synthesized with the first synthesis route ( $\mathrm{S}$ samples, in our case) is $\mathrm{Co}(\mathrm{RCOO})_{0.7}(\mathrm{OH})_{1.3} \cdot 0.75 \mathrm{H}_{2} \mathrm{O}$ while that for samples obtained via the second synthesis route ( $\mathrm{S}^{\prime}$ samples in our case) is $\mathrm{Co}(\mathrm{RCOO})_{2}$ (where RCOO corresponds globally to the carboxylate groups in Table 2).

\subsection{FTIR Spectral Characterization of the Decomposition Products}

Figure 4 represents the IR spectra of the products obtained from the thermal decomposition at $400{ }^{\circ} \mathrm{C}$ and $600{ }^{\circ} \mathrm{C}$, respectively, of the precursors of the S samples (S0, S10, S20, S30) and the $S^{\prime}$ samples ( $\left.S^{\prime} 0, S^{\prime} 10, S^{\prime} 20, S^{\prime} 30\right)$. As the spectra indicate, the bands often due to the carboxylate $(\mathrm{OCO})$ and aliphatic carbon-hydrogen $(-\mathrm{CH})$ groups are absent. On the other hand, new peaks appear at $578 \mathrm{~cm}^{-1}$ and $670 \mathrm{~cm}^{-1}$ which are attributed, respectively to the stretching vibrations of the $\mathrm{Co}^{3+}-\mathrm{O}-\mathrm{Co}^{3+}$ and $\mathrm{Co}^{3+}-\mathrm{O}-\mathrm{Co}^{2+}$ moieties, indicative of the formation of $\mathrm{a} \mathrm{Co}_{3} \mathrm{O}_{4}$ spinel structure $[9,21]$. Peaks associated with the stretching vibration of the water $/ \mathrm{OH}^{-}$group at $3450 \mathrm{~cm}^{-1}$ and the bending vibration of water at $1615 \mathrm{~cm}^{-1}$ are also observed. Even though it is not usual to find peaks due to water after calcination at $400{ }^{\circ} \mathrm{C} / 600{ }^{\circ} \mathrm{C}$, Makhlouf et al. have observed similar $-\mathrm{OH}$ in the spectra of $\mathrm{Co}_{3} \mathrm{O}_{4}$ obtained after the calcination of cobalt oxalate precursors at $773 \mathrm{~K}\left(500{ }^{\circ} \mathrm{C}\right)$ [9]. Lontio et al. also found water in the $\mathrm{Ni}_{1-x} \mathrm{Zn}_{\mathrm{x}} \mathrm{O}$ and $\mathrm{Ni}_{1-\mathrm{x}} \mathrm{Zn}_{\mathrm{x}} \mathrm{O} / \mathrm{ZnO}$ spectra obtained after calcination of the nickel zinc malonate precursor at $500{ }^{\circ} \mathrm{C}$ [27]. This tendency for metal oxide to bind hydroxide group on their surface has equally been reported by Gengnan Li et al. even though the role it plays as an inhibitor of catalytic activity is still under debate [15].

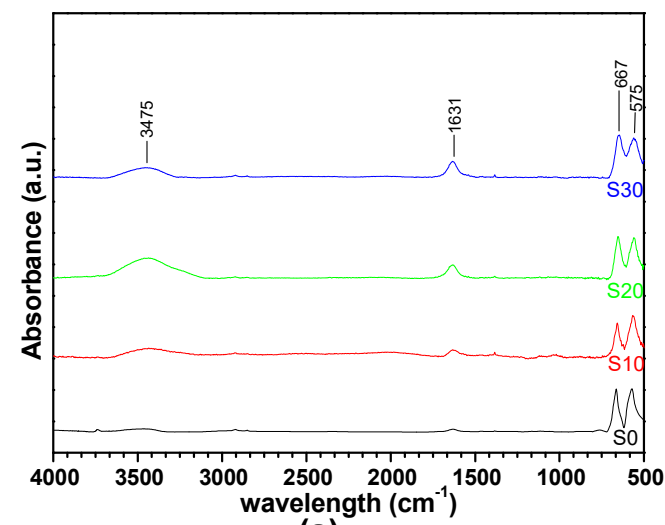

(a)

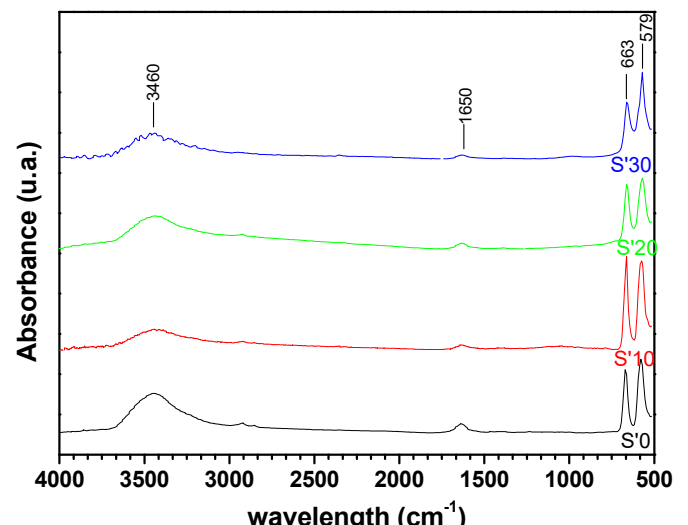

(b)

Figure 4. Infrared (IR) spectra of the decomposition products obtained from (a) S samples (S0, S10, S20, S30) calcined at $400^{\circ} \mathrm{C}$ and (b) $\mathrm{S}^{\prime}$ samples (S'0, $\left.\mathrm{S}^{\prime} 10, \mathrm{~S}^{\prime} 20, \mathrm{~S}^{\prime} 30\right)$ calcined at $600{ }^{\circ} \mathrm{C}$.

\subsection{X-ray Diffraction (XRD) Analysis of the Decomposition Products}

Figure 5 represents the XRD patterns of the thermally decomposed samples. All the diffraction peaks of sample $\mathrm{S} 0$ ( $\mathrm{S}^{\prime} 0$ ) have been perfectly indexed into the face centered cubic $\mathrm{Co}_{3} \mathrm{O}_{4}$ structures (space group $\mathrm{Fd} 3 \mathrm{~m}$ ), without any trace of other phases. This observation corroborates IR spectra. For $S$ samples $S 0$ to $S 20$ and $S^{\prime}$ samples $S^{\prime} 0$ to $S^{\prime} 10$, there is no appearance of a new phase. A new phase, identified as $\mathrm{Fe}_{3} \mathrm{O}_{4}$ appears for $\mathrm{S}$ samples in $\mathrm{S} 30$ and $S^{\prime}$ samples in S'20 (very small amount), and $S^{\prime} 30$. 


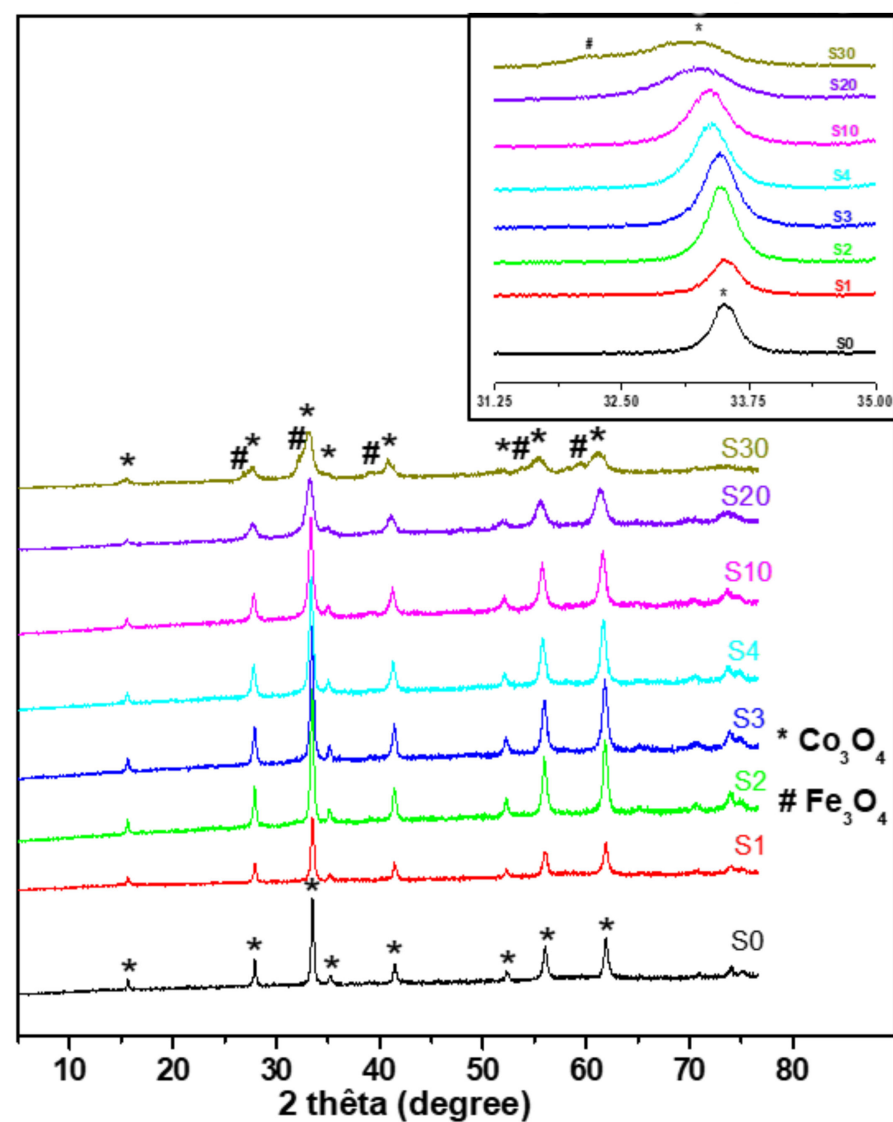

(a)

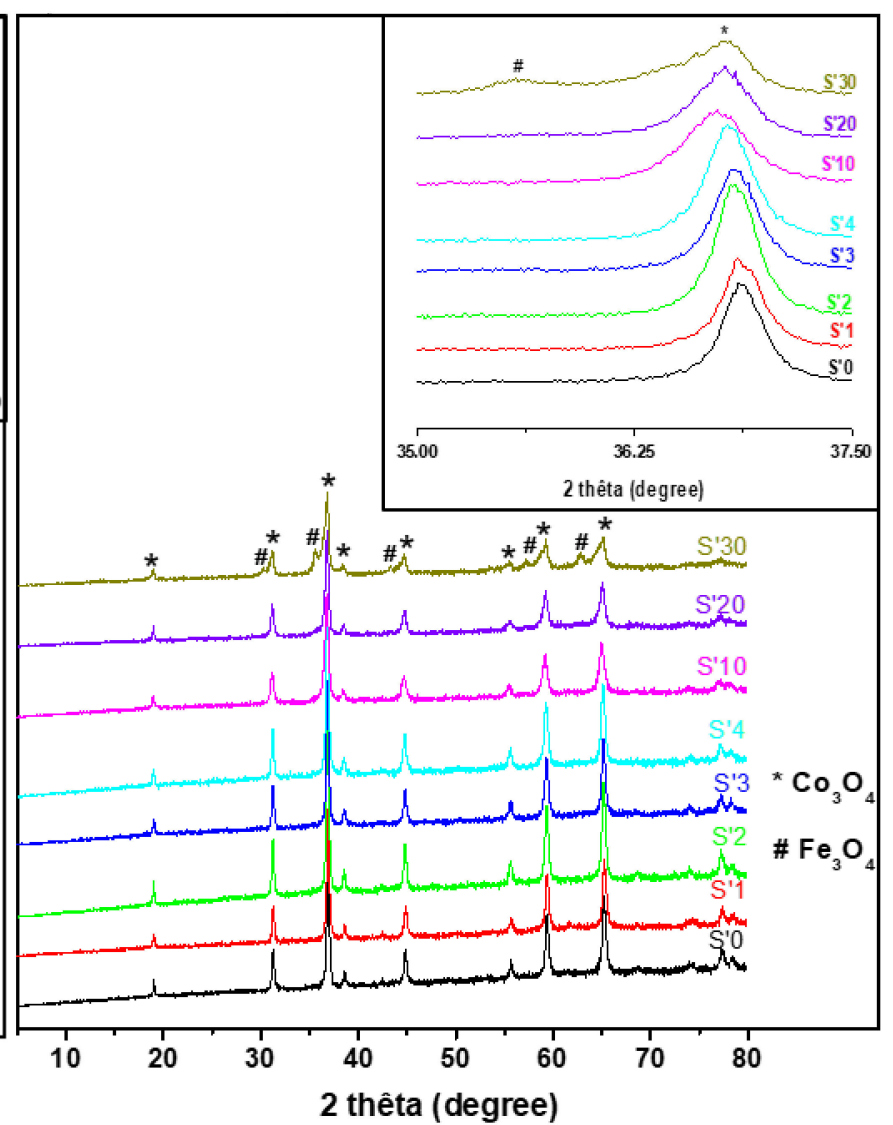

(b)

Figure 5. X-ray diffraction (XRD) of samples (a) S0 to S30, inset is zoom on the S samples highest peak; (b) $\mathrm{S}^{\prime} 0$ to $\mathrm{S}^{\prime} 30$ decomposition products, inset is zoom on the $\mathrm{S}^{\prime}$ samples highest peak. ${ }^{*} \mathrm{Co}_{3} \mathrm{O}_{4}$ diffraction peaks; \# $\mathrm{Fe}_{3} \mathrm{O}_{4}$ diffraction peaks.

The absence of a new phase for S samples, from S0 to S20 and for S' samples, from $S^{\prime} 0$ to $S^{\prime} 10$, suggests the complete substitution of cobalt ions by iron ions in the $\mathrm{Co}_{3} \mathrm{O}_{4}$ crystalline structure. This is confirmed by a perceptible shift toward the lower $2 \theta$ values of the peaks of the XRD diffraction patterns of these materials (see the insets of Figure 5) in agreement with similar works [48]. These shifts correspond to the increase in the unit cell volume due to the substitution of cobalt by iron in the $\mathrm{Co}_{3} \mathrm{O}_{4}$ unit cell because the iron ion radius is slight larger than the cobalt ion radius $\left(r\left(\mathrm{Fe}^{3+}\right)=0.64 \AA>r\left(\mathrm{Co}^{3+}\right)=0.63 \AA\right)$ for octahedral coordination [49].

Figure 6 confirms the increase of the unit cell parameter of $\mathrm{Fe}^{3+}$-doped materials with the increasing iron percentage. It is also observed on Figure 5 that the width of the peaks increases with the quantity of $\mathrm{Fe}^{3+}$ ions for these doped materials. This indicates that the particle size is reduced for these doped materials. The size $D$ of the crystallites was calculated by the Debye-Scherer equation with the most intense diffraction peak of the samples.

$$
D=\frac{\lambda}{\beta \cos \theta}
$$

where $\lambda$ is the X-ray wavelength of the radiation (1.54 $\AA$ ), $\theta$ is the diffraction angle of Bragg and $\beta$ is the full width of the most intense peak. 


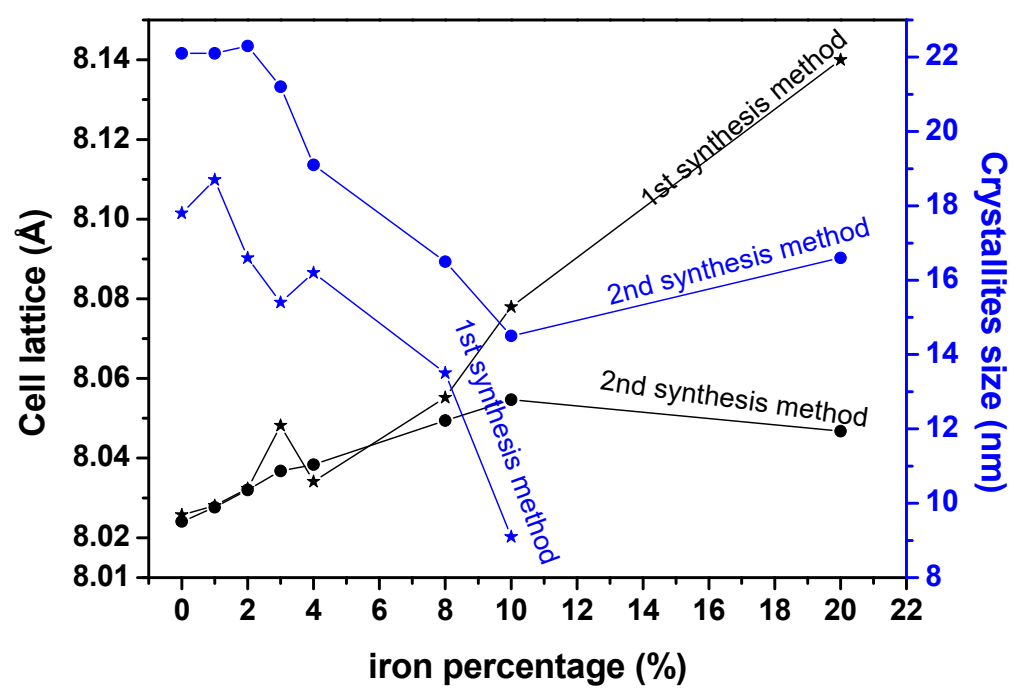

Figure 6. Variation of parameter lattice and crystallites size with iron percentage.

Figure 6 shows an overall decrease of the crystallite size till the limit of substitution of iron inside the cobalt oxide crystalline structure. For S sample S30 and S' samples S'20 and $\mathrm{S}^{\prime} 30$, where a new phase has appeared, the increase of the substitution of iron inside $\mathrm{Co}_{3} \mathrm{O}_{4}$ yields to a distortion of diffraction patterns in such a way that determination of crystallites size or cell lattice parameters was not possible. However, for the first synthesis route, even beyond the limit of substitution of iron inside the cobalt oxide structure (S20), it seems that the crystallite size continues to decrease, as we can observe on the diffraction patterns which become broader. For both methods, the particle size values of these doped samples are around or less than $20 \mathrm{~nm}$ indicating that nanomaterial are obtained by both synthetic routes. According to the literature, the degree of substitution of a metal inside a crystalline structure of another metal oxide depends on the nature of those metals and the synthesis method. S. Angelov and al. synthetized $\mathrm{Cu}_{x} \mathrm{Co}_{3-\mathrm{x}} \mathrm{O}_{4}$ by calcining the corresponding metals nitrates, and showed that beyond $x=0.9$ (30\% of metallic percentage), a new phase of $\mathrm{CuO}$ appears [50]. Li Gengnan et al. synthesized $\mathrm{Fe}_{\mathrm{x}} \mathrm{Co}_{3-\mathrm{x}} \mathrm{O}_{4}$ by co-precipitation method using oxalate as precipitant agent, and showed that the materials could be obtained for $x=1 / 3 ; 3 / 5 ; 1$ (11,11; 20 and 33,33\% of metallic percentage) [15]. Kwang Joo Kim et al. synthesized $\mathrm{Fe}_{\mathrm{x}} \mathrm{Co}_{3-\mathrm{x}} \mathrm{O}_{4}$ by spin coating mixed cobalt iron acetate dissolved in a solution 2-methoxyethanol as precursors and showed that the materials could be obtained for $x$ $=0-2$ [51]. Lontio et al. synthesized $\mathrm{Zn}_{\mathrm{x}} \mathrm{Ni}_{1-\mathrm{x}} \mathrm{O}$ by co-precipitation using malonate as precipitant agent and showed that beyond $x=0.15$, a new phase $\mathrm{ZnO}$ appeared [27].

\subsection{Raman Analysis of the Thermal Decomposition Products}

Raman spectroscopy is well known to be very sensitive to the microstructure of nanocrystal materials. Figure 7 gives the Raman spectrum of the decomposition products for samples synthesized by the first synthesis route. In accordance with the group theory prediction and other works reported on $\mathrm{Co}_{3} \mathrm{O}_{4}$ nanoparticles characterization [26,52-54], five main peaks are observed, $3 \mathrm{~F}_{2 \mathrm{~g}}, \mathrm{E}_{\mathrm{g}}$, and $\mathrm{A}_{1 \mathrm{~g}}$. The intense band at $685.7 \mathrm{~cm}^{-1}$ is characteristic of the symmetric stretching vibration of octahedral sites $\left(\mathrm{CoO}_{6}\right)$ associated to the $\mathrm{A}_{1 \mathrm{~g}}$ symmetry. The Raman bands with medium intensity located at 477.7 and $519.8 \mathrm{~cm}^{-1}$ indicate $\mathrm{E}_{\mathrm{g}}$ and $\mathrm{F}_{2 \mathrm{~g}}{ }^{2}$, respectively, while the weak band located at $613.4 \mathrm{~cm}^{-1}$ has $\mathrm{F}_{2 \mathrm{~g}}{ }^{1}$ symmetry. The band at $199.7 \mathrm{~cm}^{-1}$ is attributed to the characteristics of the tetrahedral sites $\left(\mathrm{CoO}_{4}\right)$ which are attributed to the $\mathrm{F}_{2 \mathrm{~g}}{ }^{3}$ symmetry [52]. 


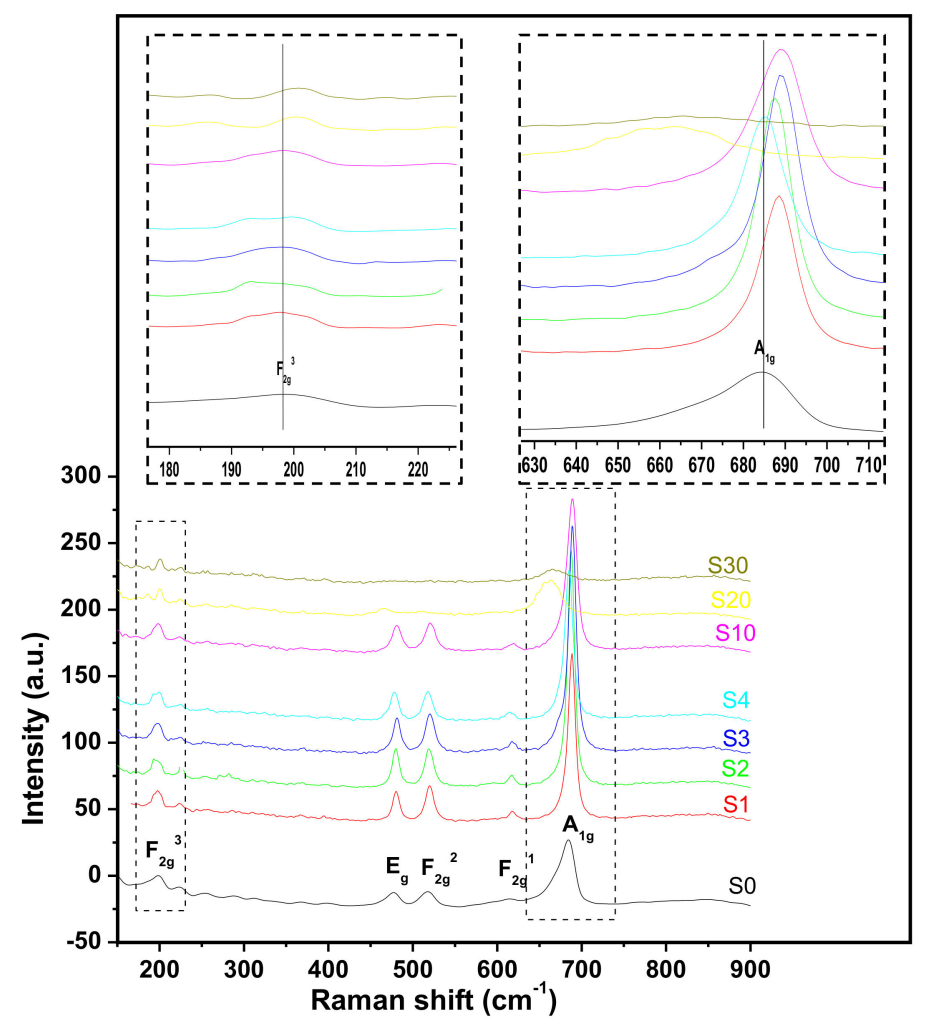

Figure 7. Raman spectra of samples S0, S1, S2, S3, S4, S10, S20 and S30 obtained by the first synthesis route. Inset is zoom of $\mathrm{F}_{2 \mathrm{~g}}{ }^{3}$ and $\mathrm{A}_{1 \mathrm{~g}}$ peaks located respectively at $200 \mathrm{~cm}^{-1}$ and $685.7 \mathrm{~cm}^{-1}$.

The random variation of the $\mathrm{A}_{1 \mathrm{~g}}$ band position with increasing amount of iron percentage while $\mathrm{F}_{2 \mathrm{~g}}{ }^{3}$ band position doesn't shift suggests that the substitution of iron by cobalt take place predominantly in octahedral sites. Lattice disorder and low dimension crystal lead to the asymmetrical broadening and downshifting of $A_{1 g}$. However for samples S20 and S30, all the peaks become wider and are shifted towards a small wavenumber. This could be attributed to the particle size because of small particles scattering at so large angle that it becomes difficult to get defined peaks [53]. However, this analysis gives no new information about the obtained products (like the substitution of metal in a preferential metal site). It has not been performed on products obtained by the second synthesis route.

\subsection{X-ray Photoelectron Spectroscopy (XPS) Analysis of the Thermal Decomposition Products}

S Samples S0, S10, S20, S30 and S' samples $S^{\prime} 0, S^{\prime} 10, S^{\prime} 20, S^{\prime} 30$ have been analyzed by XPS. Multiplet decomposition, described by Biesinger et al. [55], was used to fit the Fe 2p and Co $2 \mathrm{p}$ regions. Due to the complexity of this decomposition, only the global envelops corresponding to $\mathrm{Co}_{3} \mathrm{O}_{4}$ (blue) and $\mathrm{Fe}_{3} \mathrm{O}_{4}$ (brown) are shown here. Figure 8 displays the high-resolution spectrum corresponding to $\mathrm{Co} 2 \mathrm{p}$ and $\mathrm{Fe} 2 \mathrm{p}$ photoemissions. They show spin-orbit splitting into $2 \mathrm{p} 1 / 2$ and $2 \mathrm{p} 3 / 2$. Co $2 \mathrm{p} 3 / 2$ and $\mathrm{Co}_{\mathrm{N}} 2 \mathrm{p} 1 / 2$ are located respectively at 780 and at $794.4 \mathrm{eV}$ while $\mathrm{Fe} 2 \mathrm{p} 3 / 2$ and $\mathrm{Fe} 2 \mathrm{p} 1 / 2$ are located respectively at 711 and $724 \mathrm{eV}$. They result from the overlapping of the contribution of $\mathrm{Co}^{2+} / \mathrm{Co}^{3+}$ and $\mathrm{Fe}^{2+} / \mathrm{Fe}^{3+}$. Both $2 \mathrm{p} 1 / 2$ and 2p3/2 lines contain qualitatively the same chemical information [56]. Therefore, only the higher intensity lines with their shake-up satellite, for each element, are used to determine the contribution of each oxidation state. 


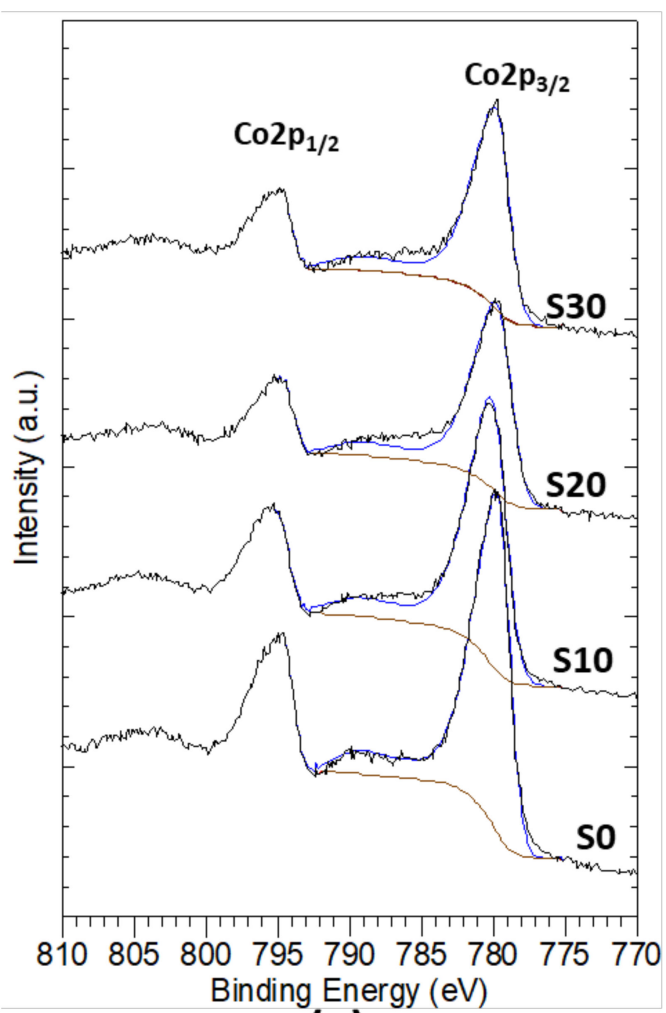

(a)

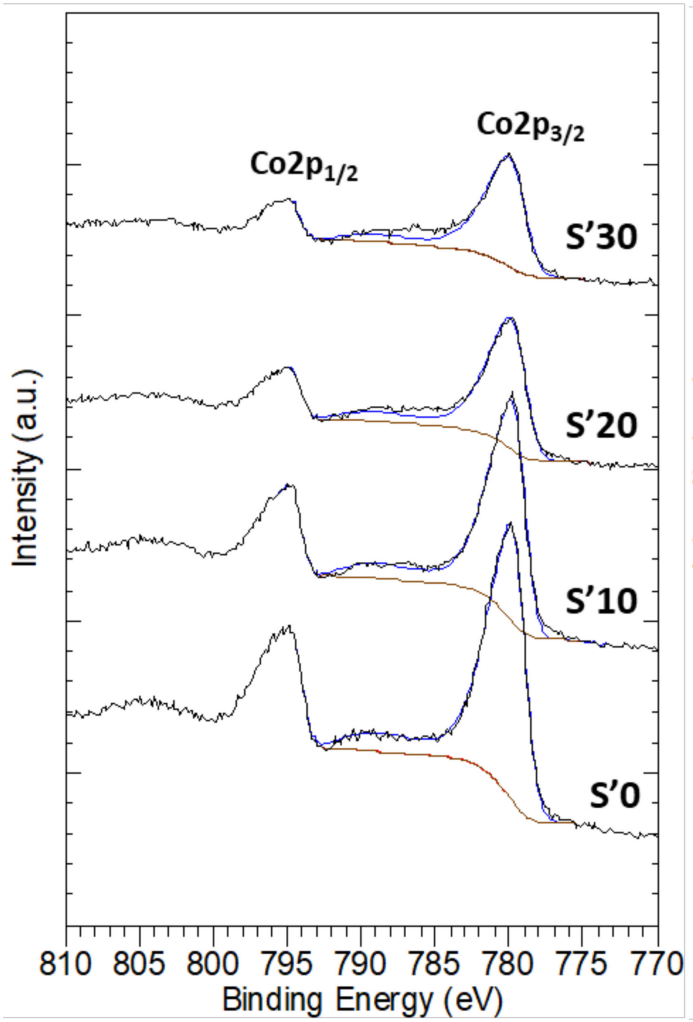

(c)

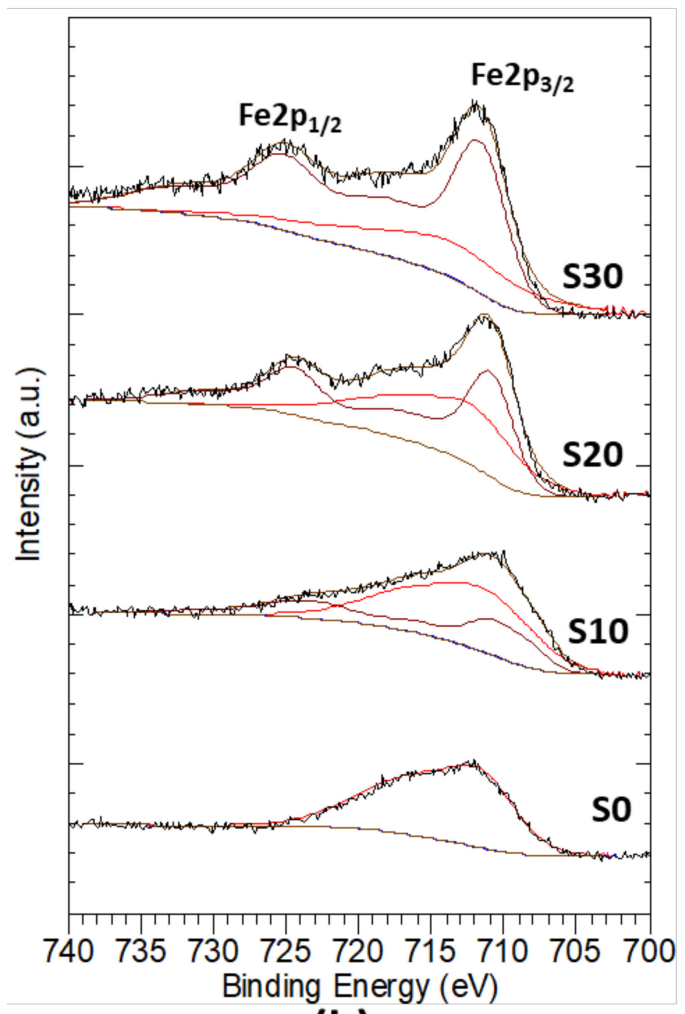

(b)

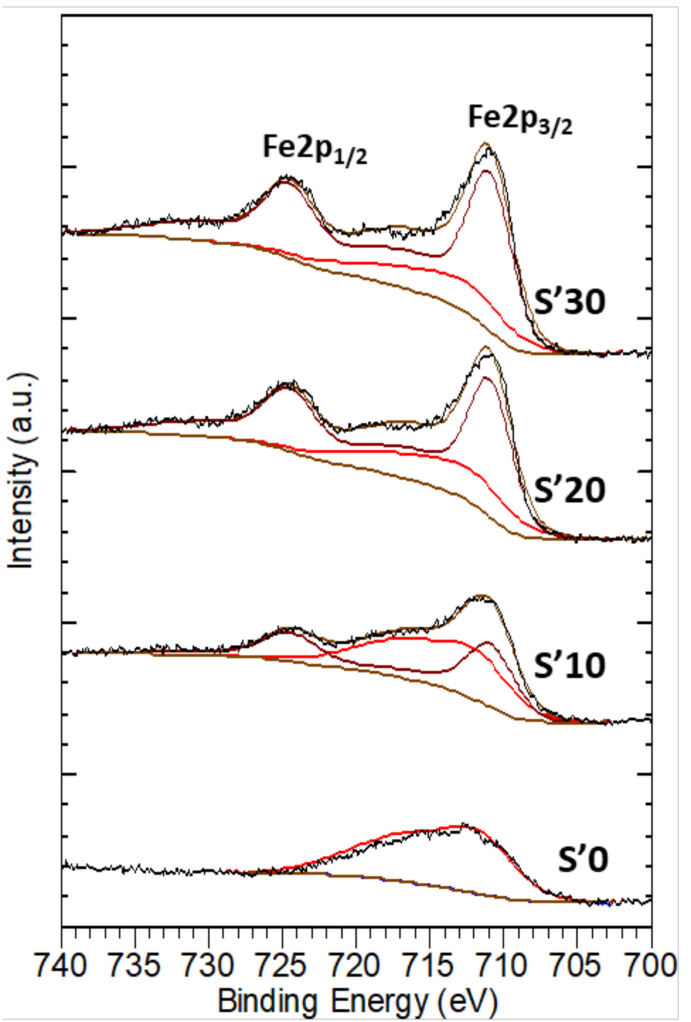

(d)

Figure 8. High-resolution X-ray photoelectron spectroscopy (XPS) spectra showing the Co 2p and Fe 2p lines of samples S0, $\mathrm{S} 10, \mathrm{~S} 20, \mathrm{~S} 30(\mathbf{a}, \mathbf{b})$ and $\mathrm{S}^{\prime} 0, \mathrm{~S}^{\prime} 10, \mathrm{~S}^{\prime} 20, \mathrm{~S}^{\prime} 30(\mathbf{c}, \mathbf{d})$. 
Information about the relative proportion of each oxidation state of cobalt ion is usually determined by considering their satellite. The Cobalt(II) oxide has a strong shakeup satellite at about $5.9 \mathrm{eV}(785 \mathrm{eV})$ above the $\mathrm{Co} 2 \mathrm{p} 3 / 2$ main peak which is absent in Co(III) complexes [57-59] or very low [56]. As Li Gengnan noted, for samples S0, S10, S20, S30 and samples $S^{\prime} 0, S^{\prime} 10, S^{\prime} 20, S^{\prime} 30$ we observe a progressive decrease of the contribution of those satellites with the increasing amount of iron, this implies an increasing of $\mathrm{Co}^{3+}$ species contribution at the surface of material [15]. It could be an important result since it has been proven that only octahedral sites occupied by $\mathrm{Co}^{3+}$ are responsible of the properties attributed to $\mathrm{Co}_{3} \mathrm{O}_{4}[12,60,61]$. However, the previous analysis does not take into account that the insertion of a hetero atom modifies the environment around the targeted atom.

The binding energy of iron electrons emitted by the photoelectric effect overlaps with the one of cobalt electrons emitted by the Auger effect. Therefore, the XPS spectra of iron have been obtained by subtracting the contribution of Auger electrons of cobalt, fitted to the spectra of samples $\mathrm{S} 0$ and $\mathrm{S}^{\prime} 0$, from all the Fe $2 \mathrm{p}$ spectra. One can observe the Fe $2 \mathrm{p} 3 / 2$ and Fe 2p1/2 lines at 711 and $725 \mathrm{eV}$, respectively, which are characteristic of iron(III) oxide $[62,63]$. The absence of peak at $707 \mathrm{eV}$ indicates that there is no metallic iron on the surface. We note the absence of shake-up satellite at about $714 \mathrm{eV}$, which would be characteristic of iron (II) oxide. This suggests that almost all the iron atoms at the surface are in the $\mathrm{Fe}$ (III) state. However, according to the fact that this analysis considers that the contribution of cobalt Auger electrons in mixed sample S10, S20, S30 remains the same as in the pure sample S0, reservations have to be made.

The XPS spectra of O 1s are presented on Figure S1 (see supplementary information). The shape of the $\mathrm{O} 1 \mathrm{~s}$ peaks shows the presence of at least two components. The first, which is relatively narrow and centered around $530.0 \mathrm{eV}$, is attributed to the lattice oxygen of the mixed cobalt-iron oxide phases. The second is much larger and centered around $532 \mathrm{eV}$. It can be assigned to the oxygen bound to contaminated carbon and to hydroxyl groups attached to the material surface [55]. This result corroborates well the FTIR analysis where the hydroxyl groups appear on the spectra.

Table 4 compares the expected values with the ICP and XPS data. The ICP analyses of samples obtained by the second synthesis route were performed on calcined samples.

Table 4. Comparison of results of atomic Fe/Co ratio obtained by different analysis techniques.

\begin{tabular}{lccccccccc}
\hline & & \multicolumn{3}{c}{ 1st Synthesis Method } & \multicolumn{4}{c}{ 2nd Synthesis Method } \\
\hline & Elements & S0 & S10 & S20 & S30 & $S^{\prime} 0$ & $S^{\prime} 10$ & $S^{\prime 2} 20$ & $S^{\prime} 30$ \\
Calculated & Fe/Co & 0 & 0.11 & 0.25 & 0.43 & 0 & 0.11 & 0.25 & 0.43 \\
ICP results & Fe/Co & 0 & 0.11 & 0.25 & 0.41 & 0 & 0.12 & 0.24 & 0.48 \\
XPS results & Fe/Co & 0 & 0.12 & 0.27 & 0.65 & 0 & 0.18 & 0.64 & 0.84 \\
\hline
\end{tabular}

According to the data presented in Table 4, the composition of the surface and the bulk are similar for samples obtained by the first synthesis route, except sample S30. It is explained by the appearance of the new phase $\mathrm{Fe}_{3} \mathrm{O}_{4}$. For the samples obtained by the second synthesis route, the $\mathrm{Fe} / \mathrm{Co}$ ratio is higher at the surface than in the bulk. This reveals a strong tendency of iron to migrate at the surface of the material for sample $S^{\prime} 10$ (obtained: 0.18 , expected: 0.11 ), where iron is completely inserted inside the cobalt oxide structure. The difference between expected and obtained $\mathrm{Fe} / \mathrm{Co}$ ratio is even more important for sample $S^{\prime} 20$ (obtained: 0.64, expected: 0.25 ) and $S^{\prime} 30$ (obtained: 0.84; expected: 0.43). Again, this can tentatively be attributed to the formation of the separate $\mathrm{Fe}_{3} \mathrm{O}_{4}$ phase.

\subsection{ToF-SIMS Analysis of the Thermal Decomposition Products}

The presence of iron in the $\mathrm{Co}_{3} \mathrm{O}_{4}$ spinel structure is corroborated by ToF-SIMS. Figure 9 shows the partial negative secondary ion mass spectra corresponding to the mass ranges of ions $\mathrm{FeCoO}_{3}{ }^{-}$and $\mathrm{FeCoO}_{4}{ }^{-}$, for samples S0 and S20 after calcination. The identification of these two mixed-metal ion peaks, absent from the pure cobalt oxide 
sample S0, indicates the proximity of the two types of atoms at the nanoscale in sample S20.

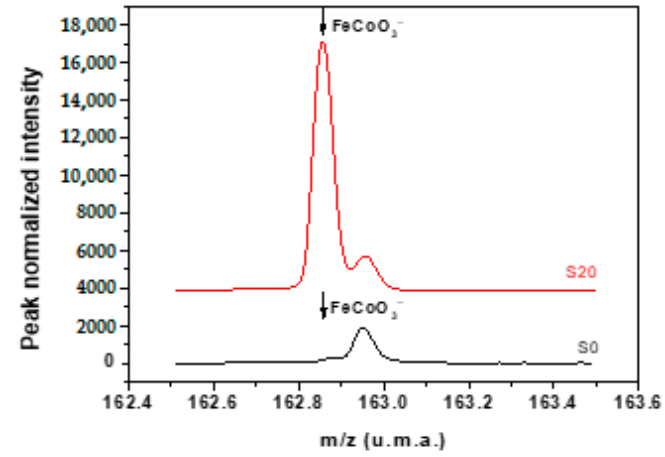

(a)

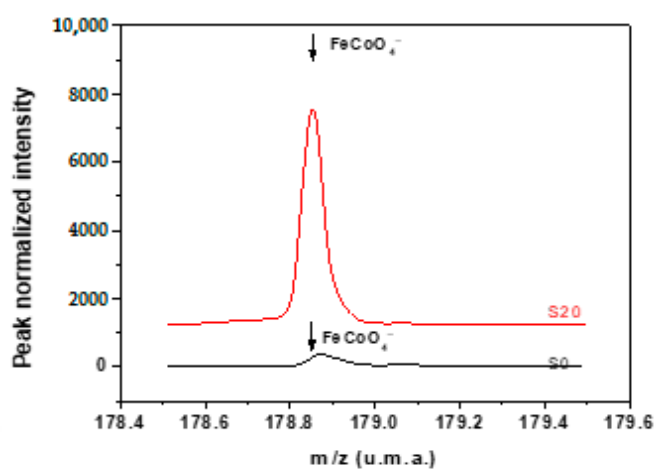

(b)

Figure 9. Partial negative spectra of $\mathrm{S} 0$ and $\mathrm{S} 20$ decomposition products showing the (a) $\mathrm{FeCoO}_{3}{ }^{-}$; (b) $\mathrm{FeCoO}_{4}{ }^{-}$peak. The peak's intensities are normalized with the respect to the total spectrum intensity (total spectrum).

Indeed, in SIMS, $10-30 \mathrm{Bi}_{3-5}{ }^{+}$primary ions eject matter from a hemispherical crater that is smaller than $10 \mathrm{~nm}$ of radius in inorganic materials such as metals or their oxides (e.g., 4-5 nm for $10 \mathrm{KeV} \mathrm{Bi}_{3-5}$ impinging on $\mathrm{Au}$ [64]). The presence of those additional ion peaks, which contain both iron and cobalt, confirm that the two metals are present in close vicinity, most probably in the same $\geq 10 \mathrm{~nm}$ particles.

The variation of the $\mathrm{FeCoO}_{3}{ }^{-}$and $\mathrm{FeCoO}_{4}{ }^{-}$peak intensities, normalized by the total spectrum intensities, with an increasing amount of iron was investigated and the results are presented in Figure 10.

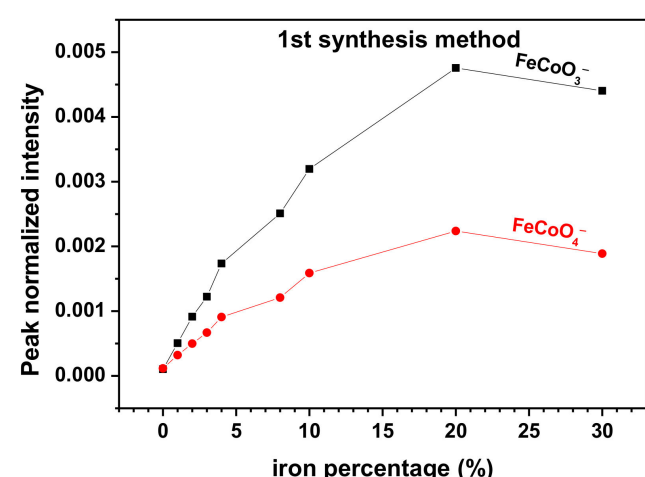

(a)

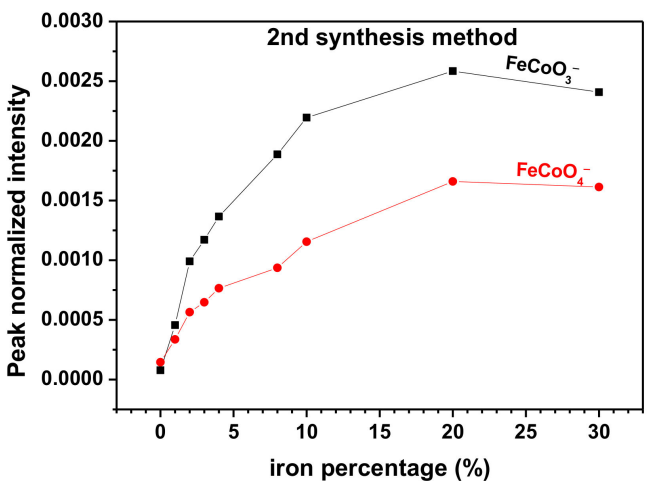

(b)

Figure 10. Variation of the intensities of the $\mathrm{FeCoO}_{3}{ }^{-}$and $\mathrm{FeCoO}_{4}{ }^{-}$ions normalized by the total spectrum intensity as a function of the Fe percentage for (a) the first synthetic route; (b) the second synthetic route.

For both synthetic routes, the intensities of the $\mathrm{FeCoO}_{3}{ }^{-}$and $\mathrm{FeCoO}_{4}{ }^{-}$ions increase with the ion percentage up to $20 \%$ of iron. The increase can be explained by the fact that, up to that point, all the iron (or almost all in the case of sample $S^{\prime 20}$ ) is inserted in the $\mathrm{Co}_{3} \mathrm{O}_{4}$ structure. This corroborates the XRD results, which indicate that there is only one crystalline phase of the spinel type up to $20 \%$ of substitution of cobalt by iron. However, for sample S30 and S'30, we observe a decrease of the normalized intensities of $\mathrm{FeCoO}_{3}{ }^{-}$and $\mathrm{FeCoO}_{4}{ }^{-}$. This is explained by the fact that beyond $20 \%$ of insertion of iron inside $\mathrm{Co}_{3} \mathrm{O}_{4}$, the new phase $\mathrm{Fe}_{3} \mathrm{O}_{4}$ starts to occupy the analyzed surface. As the represented intensities are normalized by the total intensity, the decrease of $\mathrm{FeCoO}_{3}{ }^{-}$and $\mathrm{FeCoO}_{4}{ }^{-}$intensity simply mirrors the gradual reduction of the surface area covered by the mixed oxide in 
favor of the $\mathrm{Fe}_{3} \mathrm{O}_{4}$ phase. Lontio Fomekong et al. have reported similar observations when studying the insertion of $\mathrm{Zn}$ inside the $\mathrm{NiO}$ structure [27].

The presence of an excess of iron, at the surface of the decomposition products, obtained by the second synthesis method was also corroborated by ToF-SIMS results. Figure $\mathrm{S} 2$ (confer supporting information) compares the intensity ratios of $\frac{\mathrm{FeO}_{2}^{-}}{\mathrm{FeO}_{2}^{-}+\mathrm{CoO}_{2}^{-}}$with increasing amount of iron, obtained by the two synthesis methods. The intensity ratios of $\frac{\mathrm{FeO}_{2}^{-}}{\mathrm{FeO}_{2}^{-}+\mathrm{CoO}_{2}^{-}}$increases with the amounts of iron, for both $\mathrm{S}$ and $\mathrm{S}^{\prime}$ samples. However, it is obvious that this ratio is higher for $S^{\prime}$ samples $\left(S^{\prime} 10, S^{\prime} 20, S^{\prime} 30\right)$ than for $S$ samples (S10, S20, S30).

\subsection{Transmission Electron Microscopy (TEM) Analysis of the Decomposition Products}

TEM images of the obtained samples (Figure 11) reveal a polycrystalline nature. For sample S0, S10 and S30 obtained with the first synthesis method, the TEM images show that there is not a well-defined and uniform shape. However, a tendency toward hexagonal shapes is observed. Sample $S^{\prime} 0$ and $S^{\prime} 10$ obtained by the second synthetic route exhibit a more uniform morphology. A closer look at the crystal edges also reveals hexagonal shapes for those two samples. In contrast, $\mathrm{S}^{\prime} 20$ displays diamond shapes. This suggests that the crystallite shapes are better defined using the second synthesis route, with shapes varying with the amount of iron in the sample. The crystallite sizes revealed by TEM are in the sub- $50 \mathrm{~nm}$ range, with some variation across the synthetic routes and iron percentages and a distribution of sizes in each sample. This roughly corroborates the estimates from XRD analysis which, for instance, provided values of $20 \mathrm{~nm}$ for samples S0 and $S^{\prime} 0$. In the literature, $\mathrm{Co}_{3} \mathrm{O}_{4}$ particles have been synthesized with various morphologies such as hollow nanospheres [65], nanowires [66], nanotubes [67,68] and octahedrons [69]. The properties of $\mathrm{Co}_{3} \mathrm{O}_{4}$ nanoparticles are known to vary with their shape, size and crystallization conditions.
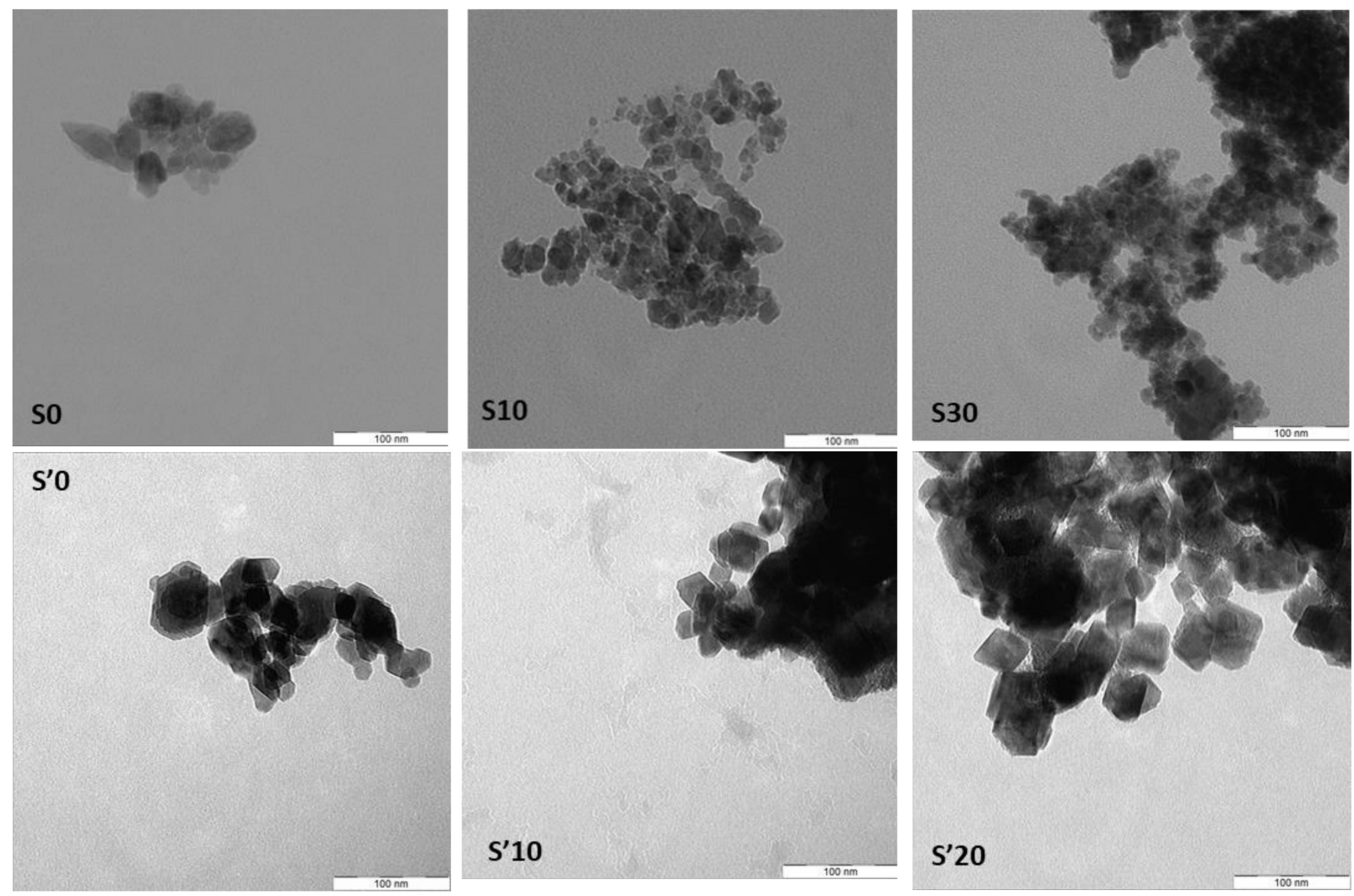

Figure 11. Transmission electron microscopy (TEM) images of the decomposition products $S 0, S 10, S_{30}$ and $S^{\prime} 0, S^{\prime} 10, S^{\prime} 20$. 


\section{Conclusions}

Nanoparticles of mixed cobalt-iron oxide, $\left(\mathrm{Co}_{(1-\mathrm{x})} \mathrm{Fe}_{\mathrm{x}}\right)_{3} \mathrm{O}_{4}(\mathrm{x}=0-0.1)$, and the composite materials, $\left(\mathrm{Co}_{(1-\mathrm{x})} \mathrm{Fe}_{\mathrm{x}}\right)_{3} \mathrm{O}_{4} / \mathrm{Fe}_{3} \mathrm{O}_{4}(\mathrm{x}>0.2)$, have been obtained by green synthesis via co-precipitation at a relatively low temperature $\left(400-600^{\circ} \mathrm{C}\right)$ using, for the first time, a hetero-metal carboxylate precursor extracted from palm kernel oil, a Cameroonian local oil product. For the synthesis of the hetero-metallic carboxylate precursors from the oil, two methods were employed, the first in which the excess $\mathrm{OH}^{-}$ions in solution were not neutralized and the second in which neutralization was carried out. The nature of both types of precursor was partially elucidated using Fourier transform infrared (FTIR) spectroscopy, thermogravimetric analysis (TGA), gas chromatography (GC) and ICP-AES while the structure and stoichiometry of the hetero-metal oxide nanoparticles, obtained from the precursors by thermal decomposition, were determined by XRD, FTIR, EDX-SEM, ToF-SIMS, XPS and TEM. XRD results, in particular, showed that the particle sizes of the calcination products (hetero-metal oxides) obtained from the neutralized precursors decreased from 22 to $14 \mathrm{~nm}$ with increasing substitution of $\mathrm{Fe}$ in the $\mathrm{Co}_{3} \mathrm{O}_{4}$ lattice while those from the non-neutralized precursors were agglomerated and decreased from 20 to 9 $\mathrm{nm}$. XRD and Raman spectroscopy show that the particles obtained are crystalline while ToF-SIMS confirms the presence of $\mathrm{Fe}$ in the $\mathrm{Co}_{3} \mathrm{O}_{4}$ lattice. XPS and ToF-SIMS indicate that the composition in the bulk and the surface materials remains the same for samples obtained using the first synthesis method while for the second synthesis method, iron is more concentrated on the surface.

The availability of palm kernel oil in copious quantities all over Cameroon implies that these (hetero-metal oxides) and other such materials could be synthesized on an industrial scale.

Supplementary Materials: The following are available online at https://www.mdpi.com/article/10 $.3390 /$ nano11112833/s1, Figure S1. High resolution XPS spectra showing the O 1s lines of samples (a) S0, S10, S20, S30 and (b) $\mathrm{S}^{\prime} 0, \mathrm{~S}^{\prime} 10, \mathrm{~S}^{\prime} 20, \mathrm{~S}^{\prime} 30$. Figure S2. SIMS intensity ratio $\mathrm{FeO}_{2}{ }^{-} /\left(\mathrm{FeO}_{2}{ }^{-}+\right.$ $\mathrm{CoO}_{2}{ }^{-}$) with the increasing amount of iron, measured on calcined samples obtained with the 1st synthesis method and the 2nd synthesis method.

Author Contributions: Conceptualization, J.L.N., A.D. and C.N.Y.; Methodology, C.N.Y. and R.L.F.; Software, C.N.Y., F.D., P.K.T. and E.M. Validation, A.D., J.L.N. and S.H.; Formal Analysis, C.N.Y., F.D., E.M. and Y.L.; Investigation, C.N.Y.; Resources, A.D., J.L.N., S.H. and Y.L.; Data Curation, C.N.Y., P.K.T., F.D., E.M. and A.D.; Writing-Original Draft Preparation, C.N.Y.; Writing-Review \& Editing, R.L.F., P.K.T., C.N.Y., J.L.N. and A.D.; Visualization, J.L.N. and A.D.; Supervision, A.D. and J.L.N.; Project Administration, A.D.; Funding Acquisition, A.D. All authors have read and agreed to the published version of the manuscript.

Funding: This research was funded by the CONSEIL DE L'ACTION INTERNATIONALE of UCLOUVAIN, through the scholarship program "Coopération au developpement", ef: SPER/LJB/742.

Institutional Review Board Statement: Not applicable.

Informed Consent Statement: Not applicable.

Data Availability Statement: Data is contained within the article or Supplementary Materials.

Acknowledgments: Authors sincerely thank Pierre Eloy for XPS analysis, Claude Poleunis for ToFSIMS analysis, Elodie Devos and Anne Iserentant for ICP analysis, Jean-François Statsyns for the calcination of the samples.

Conflicts of Interest: The authors declare no conflict of interest.

\section{References}

1. Roduner, E. Size matters: Why nanomaterials are different. Chem. Soc. Rev. 2006, 35, 583-592. [CrossRef]

2. Shahid, R. Green Chemical Synthesis of II-VI Semiconductor Quantum Dots. Ph.D. Thesis, KTH Royal Institute of Technology, Stockholm, Sweden, 2012.

3. Sahoo, P.; Djieutedjeu, H.; Poudeu, P.F.P. $\mathrm{Co}_{3} \mathrm{O}_{4}$ nanostructures: The effect of synthesis conditions on particles size, magnetism and transport properties. J. Mater. Chem. A 2013, 1, 15022-15030. [CrossRef] 
4. Lou, X.; Han, J.; Chu, W.; Wang, X.; Cheng, Q. Synthesis and photocatalytic property of $\mathrm{Co}_{3} \mathrm{O}_{4}$ nanorods. Mater. Sci. Eng. B 2007, 137, 268-271. [CrossRef]

5. Maniak, G.; Stelmachowski, P.; Stanek, J.J.; Kotarba, A.; Sojka, Z. Catalytic properties in $\mathrm{N}_{2} \mathrm{O}$ decomposition of mixed cobalt-iron spinels. Catal. Commun. 2011, 15, 127-131. [CrossRef]

6. Yamaura, H.; Tamaki, J.; Moriya, K.; Miura, N.; Yamazoe, N. Highly Selective CO Sensor Using Indium Oxide Doubly Promoted by Cobalt Oxide and Gold. J. Electrochem. Soc. 1997, 144, L158-L160. [CrossRef]

7. Chidambaram, K.; Malhotra, L.K.; Chopra, K.L. Spray-pyrolysed cobalt black as a high temperature selective absorber. Thin Solid Films 1982, 87, 365-371. [CrossRef]

8. Kim, H.-K.; Seong, T.-Y.; Lim, J.-H.; Ii Cho, W.; Soo Yoon, Y. Electrochemical and structural properties of radio frequency sputtered cobalt oxide electrodes for thin-film supercapacitors. J. Power Sources 2001, 102, 167-171. [CrossRef]

9. Makhlouf, S.A. Magnetic properties of $\mathrm{Co}_{3} \mathrm{O}_{4}$ nanoparticles. J. Magn. Magn. Mater. 2002, 246, 184-190. [CrossRef]

10. Maruyama, T.; Arai, S. Electrochromic Properties of Cobalt Oxide Thin Films Prepared by Chemical Vapor Deposition. J. Electrochem. Soc. 1996, 143, 1383-1386. [CrossRef]

11. Salavati-Niasari, M.; Mir, N.; Davar, F. Synthesis and characterization of $\mathrm{Co}_{3} \mathrm{O}_{4}$ nanorods by thermal decomposition of cobalt oxalate. J. Phys. Chem. Solids 2009, 70, 847-852. [CrossRef]

12. Omata, K.; Takada, T.; Kasahara, S.; Yamada, M. Active site of substituted cobalt spinel oxide for selective oxidation of $\mathrm{COH}_{2}$. Part II. Appl. Catal. A Gen. 1996, 146, 255-267. [CrossRef]

13. Abu-Zied, B.M.; Bawaked, S.M.; Kosa, S.A.; Schwieger, W. Effect of Pr, Sm, and Tb Doping on the Morphology, Crystallite Size, and $\mathrm{N}_{2} \mathrm{O}$ Decomposition Activity of $\mathrm{Co}_{3} \mathrm{O}_{4}$ Nanorods. J. Nanomater. 2015, 2015, 580582. [CrossRef]

14. Yan, L.; Ren, T.; Wang, X.; Ji, D.; Suo, J. Catalytic decomposition of $\mathrm{N}_{2} \mathrm{O}$ over $\mathrm{M}_{\mathrm{x}} \mathrm{Co}_{1-\mathrm{x}} \mathrm{Co}_{2} \mathrm{O}_{4}(\mathrm{M}=\mathrm{Ni}$, $\mathrm{Mg})$ spinel oxides. Appl. Catal. B Environ. 2003, 45, 85-90. [CrossRef]

15. Li, G.; Li, L.; Li, Y.; Shi, J. Highly Moisture-resistant Fe-doped Mesoporous $\mathrm{Co}_{3} \mathrm{O}_{4}$ Catalyst for Efficient Low-temperature CO Oxidation. New J. Chem. 2014, 39. [CrossRef]

16. Manickam, M.; Ponnuswamy, V.; Sankar, C.; Suresh, R.; Mariappan, R.; Chandrasekaran, J. Structural, optical, electrical and electrochemical properties of $\mathrm{Fe}: \mathrm{Co}_{3} \mathrm{O}_{4}$ thin films for supercapacitor applications. J. Mater. Sci. Mater. Electron. 2017, 28 , 18951-18965. [CrossRef]

17. Stella, C.; Soundararajan, N.; Ramachandran, K. Structural, optical, and magnetic properties of $\mathrm{Mn}$ and $\mathrm{Fe}_{-} \mathrm{doped} \mathrm{Co}_{3} \mathrm{O}_{4}$ nanoparticles. AIP Adv. 2015, 4, 087104. [CrossRef]

18. Li, G.; Chen, M.; Ouyang, Y.; Yao, D.; Lu, L.; Wang, L.; Xia, X.; Lei, W.; Chen, S.-M.; Mandler, D.; et al. Manganese doped Co ${ }_{3} \mathrm{O}_{4}$ mesoporous nanoneedle array for long cycle-stable supercapacitors. Appl. Surf. Sci. 2019, 469, 941-950. [CrossRef]

19. Deng, S.; Xiao, X.; Chen, G.; Wang, L.; Wang, Y. Cd doped porous $\mathrm{Co}_{3} \mathrm{O}_{4}$ nanosheets as electrode material for high performance supercapacitor application. Electrochim. Acta 2016, 196, 316-327. [CrossRef]

20. UmaSudharshini, A.; Bououdina, M.; Venkateshwarlu, M.; Dhamodharan, P.; Manoharan, C. Solvothermal synthesis of Cu-doped $\mathrm{Co}_{3} \mathrm{O}_{4}$ nanosheets at low reaction temperature for potential supercapacitor applications. Appl. Phys. A 2021, 127, 353. [CrossRef]

21. Hao, J.; Peng, S.; Li, H.; Dang, S.; Qin, T.; Wen, Y.; Huang, J.; Ma, F.; Gao, D. A low crystallinity oxygen-vacancy-rich $\mathrm{Co}_{3} \mathrm{O}_{4}$ cathode for high-performance flexible asymmetric supercapacitors. J. Mater. Chem. A 2018, 6, 16094-16100. [CrossRef]

22. Xiong, S.; Weng, S.; Tang, Y.; Qian, L.; Xu, Y.; Li, X.; Lin, H.; Xu, Y.; Jiao, Y.; Chen, J. Mo-doped $\mathrm{Co}_{3} \mathrm{O}_{4}$ ultrathin nanosheet arrays anchored on nickel foam as a bi-functional electrode for supercapacitor and overall water splitting. J. Colloid Interface Sci. 2021, 602, 355-366. [CrossRef]

23. Niu, M.; Wang, Y.; Cheng, Y.; Chen, G.; Cui, L. Fabrication of $\mathrm{Co}_{3} \mathrm{O}_{4}$ cubic nanoframes: Facet-preferential chemical etching of Fe ${ }^{3+}$ ions to $\mathrm{Co}_{3} \mathrm{O}_{4}$ nanocubes. Mater. Lett. 2009, 63, 837-839. [CrossRef]

24. Thota, S.; Kumar, A.; Kumar, J. Optical, electrical and magnetic properties of $\mathrm{Co}_{3} \mathrm{O}_{4}$ nanocrystallites obtained by thermal decomposition of sol-gel derived oxalates. Mater. Sci. Eng. B 2009, 164, 30-37. [CrossRef]

25. Yang, Y.-P.; Liu, R.-S.; Huang, K.-L.; Wang, L.-P.; Liu, S.-Q.; Zeng, W.-W. Preparation and electrochemical performance of nanosized $\mathrm{Co}_{3} \mathrm{O}_{4}$ via hydrothermal method. Trans. Nonferrous Met. Soc. China 2007, 17, 1334-1338. [CrossRef]

26. Gu, F.; Li, C.; Hu, Y.; Zhang, L. Synthesis and optical characterization of $\mathrm{Co}_{3} \mathrm{O}_{4}$ nanocrystals. J. Cryst. Growth 2007, 304, 369-373. [CrossRef]

27. Fomekong, R.L.; Tsobnang, P.K.; Magnin, D.; Hermans, S.; Delcorte, A.; Ngolui, J.L. Coprecipitation of nickel zinc malonate: A facile and reproducible synthesis route for $\mathrm{Ni}_{1-} \mathrm{Zn}_{\mathrm{x}} \mathrm{O}$ nanoparticles and $\mathrm{Ni}_{1-} \mathrm{Zn}_{\mathrm{x}} \mathrm{O} / \mathrm{ZnO}$ nanocomposites via pyrolysis. $J$. Solid State Chem. 2015, 230, 381-389. [CrossRef]

28. Ansari, F.; Soofivand, F.; Salavati-Niasari, M. Utilizing maleic acid as a novel fuel for synthesis of $\mathrm{PbFe}_{12} \mathrm{O}_{19}$ nanoceramics via sol-gel auto-combustion route. Mater. Charact. 2015, 103, 11-17. [CrossRef]

29. Das, S.; Srivastava, V. Synthesis and characterization of copper succinate and copper oxide nanoparticles by electrochemical treatment: Optimization by Taguchi robust analysis. Can J. Chem. Eng. 2016, 94, 1322-1327. [CrossRef]

30. Sun, S.; Zeng, H. Size-controlled synthesis of magnetite nanoparticles. J. Am. Chem. Soc. 2002, 124, 8204-8205. [CrossRef]

31. Jović Orsini, N.; Babić-Stojić, B.; Spasojević, V.; Calatayud, M.P.; Cvjetićanin, N.; Goya, G.F. Magnetic and power absorption measurements on iron oxide nanoparticles synthesized by thermal decomposition of Fe(acac)3. J. Magn. Magn. Mater. 2018, 449, 286-296. [CrossRef] 
32. Kamta, H.; Kenfack, T.P.; Lontio, F.R.; Etape, E.; Joy, P.; Delcorte, A.; Lambi, J. Structural characterization and magnetic properties of undoped and copper-doped cobalt ferrite nanoparticles prepared by the octanoate coprecipitation route at very low dopant concentrations. RSC Adv. 2018, 8, 38621-38630. [CrossRef]

33. Borel, N.N.M.; Foba-Tendo, J.; Yufanyi, D.M.; Etape, E.P.; Eko, J.N.; Ngolui, L.J. Averrhoa carambola: A renewable source of oxalic acid for the facile and green synthesis of divalent metal ( $\mathrm{Fe}, \mathrm{Co}, \mathrm{Ni}, \mathrm{Zn}$, and $\mathrm{Cu}$ ) oxalates and oxide nanoparticles. J. Appl. Chem. 2014, 2014, 9 .

34. Sharma, J.K.; Srivastava, P.; Singh, G.; Akhtar, M.S.; Ameen, S. Green synthesis of $\mathrm{Co}_{3} \mathrm{O}_{4}$ nanoparticles and their applications in thermal decomposition of ammonium perchlorate and dye-sensitized solar cells. Mater. Sci. Eng. B 2015, 193, 181-188. [CrossRef]

35. Vani, P.; Manikandan, N.; Vinitha, G. A green strategy to synthesize environment friendly metal oxide nanoparticles for potential applications: A review. Asian J. Pharm. Clin. Res. 2017, 10, 337. [CrossRef]

36. Das, R.K.; Golder, A.K. $\mathrm{Co}_{3} \mathrm{O}_{4}$ spinel nanoparticles decorated graphite electrode: Bio-mediated synthesis and electrochemical $\mathrm{H}_{2} \mathrm{O}_{2}$ sensing. Electrochim. Acta 2017, 251, 415-426. [CrossRef]

37. Saeed, M.; Akram, N.; Naqvi, S.A.R.; Usman, M.; Abbas, M.A.; Adeel, M.; Nisar, A. Green and eco-friendly synthesis of $\mathrm{Co}_{3} \mathrm{O}_{4}$ and $\mathrm{Ag}-\mathrm{Co}_{3} \mathrm{O}_{4}$ : Characterization and photo-catalytic activity. Green Process. Synth. 2019, 8, 382-390. [CrossRef]

38. Kombaiah, K.; Vijaya, J.J.; Kennedy, L.J.; Kaviyarasu, K.; Ramalingam, R.J.; Al-Lohedan, H.A. Green synthesis of Co ${ }_{3} \mathrm{O}_{4}$ nanorods for highly efficient catalytic, photocatalytic, and antibacterial activities. Int. J. Nanosci. Nanotechnol. 2019, 19, 2590-2598. [CrossRef] [PubMed]

39. Waris, A.; Din, M.; Ali, A.; Afridi, S.; Baset, A.; Khan, A.U.; Ali, M. Green fabrication of Co and $\mathrm{Co}_{3} \mathrm{O}_{4}$ nanoparticles and their biomedical applications: A review. Open Life Sci. 2021, 16, 14-30. [CrossRef]

40. Rasheed, T.; Nabeel, F.; Bilal, M.; Iqbal, H. Biogenic synthesis and characterization of cobalt oxide nanoparticles for catalytic reduction of direct yellow-142 and methyl orange dyes. Biocatal. Agric. Biotechnol. 2019, 19, 101154. [CrossRef]

41. Hsu, C.-M.; Huang, Y.-H.; Chen, H.-J.; Lee, W.-C.; Chiu, H.-W.; Maity, J.P.; Chen, C.-C.; Kuo, Y.-H.; Chen, C.-Y. Green synthesis of nano- $\mathrm{Co}_{3} \mathrm{O}_{4}$ by Microbial Induced Precipitation (MIP) process using Bacillus pasteurii and its application as supercapacitor. Mater. Today Commun. 2018, 14, 302-311. [CrossRef]

42. Koyyati, R.; Kudle, K.R.; Padigya, P.R.M. Evaluation of antibacterial and cytotoxic activity of green synthesized cobalt nanoparticles using Raphanus sativus var. longipinnatus leaf extract. Int. J. Pharmtech Res. 2016, 9, 466-472.

43. Berger, K.G. Palm kernel oil. In Encyclopedia of Food Sciences and Nutrition, 2nd ed.; Caballero, B., Ed.; Academic Press: Oxford, UK, 2003; pp. 4322-4324.

44. Kapseu, C. Production, analyse et applications des huiles végétales en Afrique. Oléagineux Corps Gras Lipides 2009, 16, 215-229. [CrossRef]

45. Pantzaris, T.; Ahmad, M.J. Properties and utilization of palm kernel oil. Palm Oil Dev. 2001, 35, 19-23.

46. Folch, J.; Lees, M.; Stanley, G.S. A simple method for the isolation and purification of total lipides from animal tissues. J. Biol. Chem. 1957, 226, 497-509. [CrossRef]

47. Hassim, N.A.M.; Dian, L. Usage of palm oil, palm kernel oil and their fractions as confectionery fats. J. Oil Palm Res. 2017, 29, 301-310. [CrossRef]

48. Li, G.-H.; Dai, L.-Z.; Lu, D.-S.; Peng, S.-Y. Characterization of copper cobalt mixed oxide. J. Solid State Chem. 1990, 89, 167-173. [CrossRef]

49. Pan, K.-L.; Overstreet, W.C.; Robinson, K.; Hubert, A.E.; Crenshaw, G.L. Equivalent Uranium and Selected Minor Elements in Magnetic Concentrates from the Candle Quadrangle, Solomon Quadrangle, and Elsewhere in Alaska. 1980. Available online: https:/ / pascal-francis.inist.fr/vibad/index.php?action=getRecordDetail\&idt=PASCALGEODEBRGM8220230354 (accessed on 9 October 2021).

50. Angelov, S.; Zhecheva, E.; Petrov, K.; Menandjiev, D. The properties of a spinel copper cobaltite prepared at low temperatures and normal pressure. Mater. Res. Bull. 1982, 17, 235-240. [CrossRef]

51. Kim, K.J.; Kim, H.K.; Park, Y.R.; Ahn, G.Y.; Kim, C.S.; Park, J.Y. Magnetic and optical properties of spinel $\mathrm{Fe}_{\mathrm{x}} \mathrm{Co}_{3-\mathrm{x}} \mathrm{O}_{4}$ thin films. J. Magn. Magn. Mater. 2006, 300, 300-305. [CrossRef]

52. Gawali, S.R.; Gandhi, A.C.; Gaikwad, S.S.; Pant, J.; Chan, T.S.; Cheng, C.L.; Ma, Y.R.; Wu, S.Y. Role of cobalt cations in short range antiferromagnetic $\mathrm{Co}_{3} \mathrm{O}_{4}$ nanoparticles: A thermal treatment approach to affecting phonon and magnetic properties. Sci. Rep. 2018, 8, 249. [CrossRef]

53. Rashad, M.; Rüsing, M.; Berth, G.; Lischka, K.; Pawlis, A. CuO and $\mathrm{Co}_{3} \mathrm{O}_{4}$ Nanoparticles: Synthesis, Characterizations, and Raman Spectroscopy. J. Nanomater. 2013, 2013, 714853. [CrossRef]

54. Blakemore, J.D.; Gray, H.B.; Winkler, J.R.; Müller, A.M. $\mathrm{Co}_{3} \mathrm{O}_{4}$ Nanoparticle Water-Oxidation Catalysts Made by Pulsed-Laser Ablation in Liquids. ACS Catal. 2013, 3, 2497-2500. [CrossRef]

55. Biesinger, M.C.; Payne, B.P.; Grosvenor, A.P.; Lau, L.W.M.; Gerson, A.R.; Smart, R.S.C. Resolving surface chemical states in XPS analysis of first row transition metals, oxides and hydroxides: Cr, Mn, Fe, Co and Ni. Appl. Surf. Sci. 2011, 257, 2717-2730. [CrossRef]

56. Artyushkova, K.; Levendosky, S.; Atanassov, P.; Fulghum, J. XPS Structural Studies of Nano-composite Non-platinum Electrocatalysts for Polymer Electrolyte Fuel Cells. Top. Catal. 2007, 46, 263-275. [CrossRef]

57. Yang, J.; Liu, H.; Martens, W.N.; Frost, R.L. Synthesis and characterization of cobalt hydroxide, cobalt oxyhydroxide, and cobalt oxide nanodiscs. J. Phys. Chem. C 2010, 114, 111-119. [CrossRef] 
58. McIntyre, N.S.; Cook, M.G. X-ray photoelectron studies on some oxides and hydroxides of cobalt, nickel, and copper. Anal. Chem. 1975, 47, 2208-2213. [CrossRef]

59. Casella, I.G.; Guascito, M.R. Anodic electrodeposition of conducting cobalt oxyhydroxide films on a gold surface. XPS study and electrochemical behaviour in neutral and alkaline solution. J. Electroanal. Chem. 1999, 476, 54-63. [CrossRef]

60. Jacobs, J.P.; Maltha, A.; Reintjes, J.G.H.; Drimal, J.; Ponec, V.; Brongersma, H.H. The surface of catalytically active spinels. J. Catal. 1994, 147, 294-300. [CrossRef]

61. Shelef, M.; Wheeler, M.A.Z.; Yao, H.C. Ion scattering spectra from spinel surfaces. Surf. Sci. 1975, 47, 697-703. [CrossRef]

62. Brundle, C.; Chuang, T.; Wandelt, K. Core and valence level photoemission studies of iron oxide surfaces and the oxidation of iron. Surf. Sci. 1977, 68, 459-468. [CrossRef]

63. Graat, P.C.; Somers, M.A. Simultaneous determination of composition and thickness of thin iron-oxide films from XPS Fe 2p spectra. Appl. Surf. Sci. 1996, 100, 36-40. [CrossRef]

64. Delcorte, A.; Leblanc, C.; Poleunis, C.; Hamraoui, K. Computer Simulations of the Sputtering of Metallic, Organic, and MetalOrganic Surfaces with Bin and C60 Projectiles. J. Phys. Chem. C 2013, 117, 2740-2752. [CrossRef]

65. Wang, X.; Zhong, Y.; Zhai, T.; Guo, Y.; Chen, S.; Ma, Y.; Yao, J.; Bando, Y.; Golberg, D. Multishelled $\mathrm{Co}_{3} \mathrm{O}_{4}-\mathrm{Fe}_{3} \mathrm{O}_{4}$ hollow spheres with even magnetic phase distribution: Synthesis, magnetic properties and their application in water treatment. J. Mater. Chem. 2011, 21, 17680-17687. [CrossRef]

66. Xiao, X.; Liu, X.; Zhao, H.; Chen, D.; Liu, F.; Xiang, J.; Hu, Z.; Li, Y. Facile shape control of $\mathrm{Co}_{3} \mathrm{O}_{4}$ and the effect of the crystal plane on electrochemical performance. Adv. Mater. 2012, 24, 5762-5766. [CrossRef] [PubMed]

67. Shen, X.-P.; Miao, H.-J.; Zhao, H.; Xu, Z. Synthesis, characterization and magnetic properties of $\mathrm{Co}_{3} \mathrm{O}_{4}$ nanotubes. Appl. Phys. A 2008, 91, 47-51. [CrossRef]

68. Wang, R.; Liu, C.; Zhang, H.; Chen, C.; Guo, L.; Xu, H.; Yang, S. Porous nanotubes of $\mathrm{Co}_{3} \mathrm{O}_{4}$ : Synthesis, characterization, and magnetic properties. Appl. Phys. Lett. 2004, 85, 2080-2082. [CrossRef]

69. Chen, Y.H.; Zhou, J.F.; Mullarkey, D.; O'Connell, R.; Schmitt, W.; Venkatesan, M.; Coey, M.; Zhang, H.Z. Synthesis, characterization and magnetic properties of ultrafine $\mathrm{Co}_{3} \mathrm{O}_{4}$ octahedra. AIP Adv. 2015, 5, 087122. [CrossRef] 